\title{
Nanomaterials as Inhibitors of Epithelial Mesenchymal Transition in Cancer Treatment
}

\author{
Marco Cordani ${ }^{1, t, * \mathbb{D}}$, Raffaele Strippoli ${ }^{2,3,+} \mathbb{C}$ and Álvaro Somoza ${ }^{1,4, *}$ \\ 1 Instituto Madrileño de Estudios Avanzados en Nanociencia (IMDEA Nanociencia), 28049 Madrid, Spain \\ 2 Department of Molecular Medicine, Sapienza University of Rome, 00161 Rome, Italy; \\ raffaele.strippoli@uniroma1.it \\ 3 National Institute for Infectious Diseases “Lazzaro Spallanzani” I.R.C.C.S., 00149 Rome, Italy \\ 4 CNB-CSIC-IMDEA Nanociencia Associated Unit “Unidad de Nanobiotecnología”, 28049 Madrid, Spain \\ * Correspondence: marco.cordani@imdea.org (M.C.); alvaro.somoza@imdea.org (Á.S.) \\ $\dagger$ These authors contributed equally to this work.
}

Received: 21 November 2019; Accepted: 13 December 2019; Published: 19 December 2019

check for updates

\begin{abstract}
Epithelial-mesenchymal transition (EMT) has emerged as a key regulator of cell invasion and metastasis in cancers. Besides the acquisition of migratory/invasive abilities, the EMT process is tightly connected with the generation of cancer stem cells (CSCs), thus contributing to chemoresistance. However, although EMT represents a relevant therapeutic target for cancer treatment, its application in the clinic is still limited due to various reasons, including tumor-stage heterogeneity, molecular-cellular target specificity, and appropriate drug delivery. Concerning this last point, different nanomaterials may be used to counteract EMT induction, providing novel therapeutic tools against many different cancers. In this review, (1) we discuss the application of various nanomaterials for EMT-based therapies in cancer, (2) we summarize the therapeutic relevance of some of the proposed EMT targets, and (3) we review the potential benefits and weaknesses of each approach.
\end{abstract}

Keywords: nanomaterials; nanomedicine; epithelial-mesenchymal transition; cancer metastasis; cancer therapy

\section{Introduction}

Epithelial-mesenchymal transition (EMT) is a highly dynamic multistep process implicated in a plethora of physio-pathological conditions, including cancer. In tumors, the acquisition of EMT has been demonstrated to provide the tumor cells with new migratory-invasive abilities, and, more recently, to mediate the acquisition of chemoresistance, which is linked to cancer stem cells (CSCs)-like features [1]. Importantly, the role of EMT in tumors may differ in different experimental systems and different tumors. EMT may be required for tumor initiation, for cell delamination from the primary tumor, for cell dissemination, and chemoresistance after therapy [2].

In this sense, there is growing evidence suggesting that targeting EMT can be used as a therapeutic approach itself, or to enhance the efficacy of other anticancer treatments [3-5].

Among the standard therapeutic strategies for cancer treatment (e.g., surgery, radiation, chemotherapy), the one that can be applied at all stages, including metastasis (stage 4), is chemotherapy since it is administered systemically [6]. However, it also presents a variety of drawbacks, such as low specificity, drug resistance, rapid drug clearance, and biodegradation, which can lead to treatment failures and related mortality [7]. In the last years, the use of drug delivery systems based on nanomaterials has improved the properties of a variety of bioactive therapies, including drugs, peptides, and antibodies [8-10]. Particularly, advances in material sciences have led to the development of different nanomaterials, which typically have sizes ranging from $5 \mathrm{~nm}$ to $200 \mathrm{~nm}$ and which properties 
can be exploited to treat cancer and/or be used as nanocarriers for drug delivery. These nanosystems are employed to improve the biodistribution of chemotherapeutic drugs and their accumulation at the target site, showing encouraging results in preclinical and clinical studies [11].

In this review, we summarized a plethora of studies describing the capability of nanostructures to inhibit EMT in cancer cells and in in vivo models, leading to cell death, chemosensitivity, and inhibition of cancer cell invasion and metastasis.

\section{Epithelial to Mesenchymal Transition: From Physiology to Cancer}

After being firstly described as a process allowing lens epithelium cells to invade a 3D collagen gel [12], eEMT has been increasingly characterized in many physio-pathological conditions, such as embryonic development, wound healing, organ fibrosis, and cancer progression [1]. EMT consists of a complex multistep reprogramming of the cell proteome, in which cells progressively lose their epithelial identity while gaining mesenchymal-like features.

EMT onset may be easily traced with conventional microscopy techniques: Under the appropriate stimulus, cells progressively lose their characteristic epithelial cell-to-cell junctions, such as adherent and tight junctions, and the apical-basal polarity. At the same time, front-rear polarity is acquired, as well as migratory and invasive abilities. Among epithelial markers, E-cadherin, a constituent of adherent junctions, is rapidly downregulated and is replaced by other pro-migratory plasma cadherins, such as N-cadherin, a phenomenon called 'cadherin switch'. Similarly, intermediate epithelial filaments such as cytokeratin are replaced by mesenchymal counterparts, such as vimentin.

\subsection{EMT-TFs}

The loss of E-cadherin is mediated by basic helix loop helix (bHLH) or zinc-finger transcription factors, such as Snail-1, Twist-related protein 1 (TWIST1), and zinc finger E-box binding homeobox 1 (ZEB1) [1]. These proteins are considered master genes of EMT or EMT-activating transcription factors (EMT-TFs), since their expression is sufficient to promote EMT induction [13]. The activity of EMT-TFs often implicates the involvement of epigenetic factors, such as histone deacetylases (HDACs), methyl-transferases, and demethylases, such as lysine demethylase 1 (LSD1) [14] (Figure 1).

Besides the EMT-TFs, different TFs involved in other cellular processes play a critical role in EMT induction. For instance, NF-kB, a TF activated during inflammation, has been demonstrated to control also SNAIL-1-E-cadherin expression [15,16]; the Wingless-type MMTV integration site WNT1- $\beta$ catenin pathway links the stability of cellular junctions to the repression of EMT program in tumors [17]. 


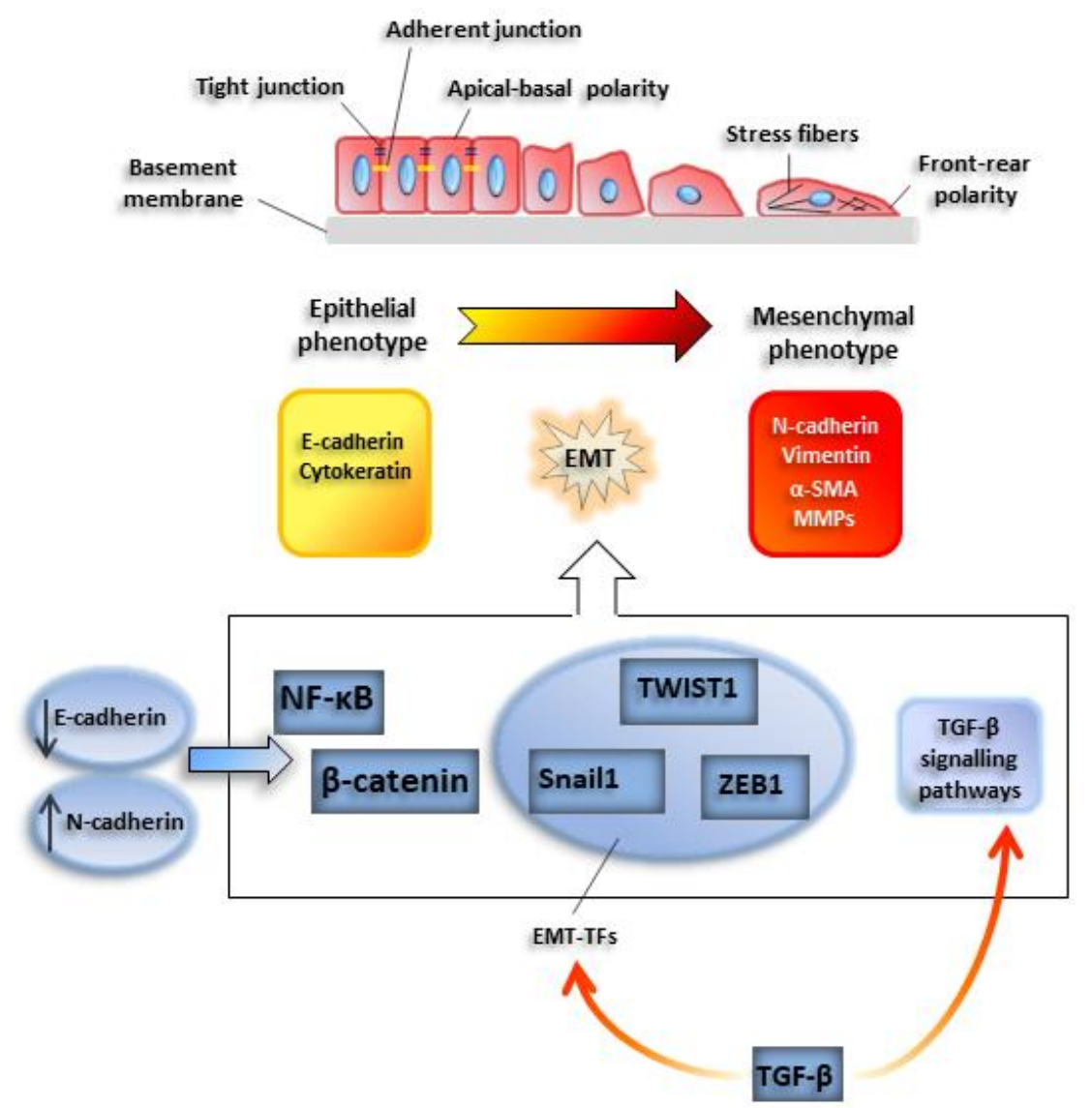

Figure 1. Outline of a typical epithelial-mesenchymal transition EMT program. Cells undergoing EMT progressively lose typical epithelial cell-to-cell junctions, such as adherent and tight junctions, and the apical-basal polarity. At the same time, cells acquire a front-rear polarity, while gaining migratory and invasive abilities. Among epithelial markers, E-cadherin, a constituent of adherent junctions, is rapidly downregulated and is replaced by N-cadherin. This phenomenon is called 'cadherin switch'. Similarly, epithelial intermediate filaments such as cytokeratins are replaced by mesenchymal counterparts, such as vimentin. Also, smooth muscle actin ( $\alpha$-SMA) is de novo induced. E-cadherin downregulation facilitates the activity of transcription factors relevant for the induction of the EMT program, such as nuclear factor kappa B subunit 1 (NF-kB) and $\beta$-catenin. Snail1, TWIST1, and ZEB1 are EMT-activating transcription factors which lead activation of EMT program.

\subsection{Extracellular Inducers of EMT: Role of TGF $\beta$}

Among the plethora of extracellular EMT inducers, proteins of the transforming growth factor $\beta$ (TGF $\beta$ ) family play a central role, inducing EMT-TFs expression. Besides their activity as transcriptional repressors, EMT-TFs such as Snail1, are direct inducers of fibronectin (FN), which is part of the extracellular matrix (ECM) proteins whose production is increased during EMT [16]. The changes in ECM composition, as well as soluble factors, cause increased expression and activation of integrins, especially of $\beta 1$ and $\beta 3$ families. This, in turn, has a role in promoting an adhesive/migratory phenotype, as well as changes in proliferation/survival [18]. Integrin signaling cooperates with signals elicited by tyrosine kinase or TGF $\beta$ induced pathways, leading to increased adhesion/motility. Besides TGF $\beta$, other extracellular factors such as tyrosine receptors ligands including Epidermal growth factor, (EGF) and Hepatocyte growth factor (HGF) and cytokines such as Interleukin6 (IL-6) [19] and Vascular endothelial growth factor (VEGF) promote EMT in different experimental systems (Figure 2). 


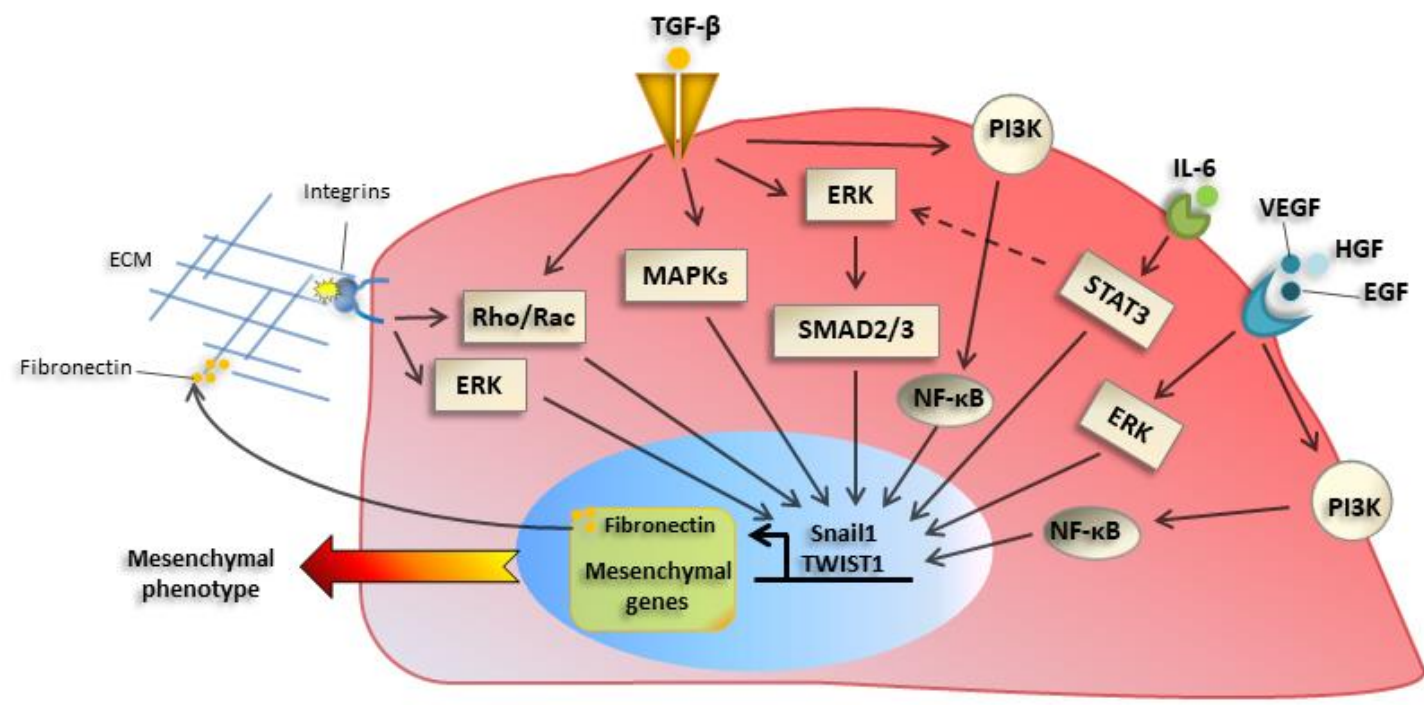

Figure 2. Main molecular mechanisms underlying EMT activation. Transforming growth factor- $\beta$ (TGF- $\beta$ ) receptor activation induces a classical mother against decapentaplegic (SMAD) pathway, as well as 'nonclassical' pathway, such as mitogen-activated protein kinase (MAPKs), Phosphoinositide 3-kinase (PI3K)- mammalian target of rapamycin (mTOR), or Rho guanosine triphosphatase (GTPases), which induce EMT-TFs such as Snail1 and TWIST1. Besides their activity as transcriptional regulators, they control the expression of mesenchymal genes and extracellular matrix (ECM) proteins, such as fibronectin and collagens, whose production is increased during EMT. The alteration of ECM composition causes changes in expression and activation of integrins, which promote migratory proprieties of cancer cells. Integrin signaling in turn sustains EMT induction through extracellular signal-regulated kinase (ERK) and Rho GTPases signaling pathways. Tyrosine receptor ligands (EGF, HGF) and cytokines, such as IL-6 and VEGF, are other factors involved in EMT activation through ERK, PI3K, and NF- $\mathrm{KB}$ pathways.

\subsection{Noncoding RNAs}

Besides the processes mentioned above, the discovery and characterization of small noncoding RNAs, such as microRNAs (miRNAs), or more recently of long noncoding RNAs added a new layer in the study of molecular mechanisms undergoing EMT induction. In this sense, molecular circuits between miRNAs and EMT-TFs have been elucidated, such as that one involving miR-200 and ZEB1 [20]. Other examples involve miRNA-29, miRNA-378b, and miRNA-26a-5p, which are direct regulators of EMT and fibrosis through collagen expression by several mechanisms, such as by inhibiting sirtuin-6 and the autophagic protein ULK-1 [21-23].

Interestingly, EMT induction is a dynamic and multistep process, and in the first phases it may be reversed. In this sense, under the appropriate stimulus, cells in a mesenchymal state may progressively lose their mesenchymal features, while recovering an epithelial identity. This process is known as mesenchymal to epithelial transition (MET). This process is characterized by the re-expression of epithelial proteins, such as E-cadherin and cytokeratins, and the downregulation of protein characteristic of the mesenchymal phenotype, such as EMT-TFs, N-cadherin, and vimentin [24,25].

\subsection{Specificities of Tumor EMT}

Although EMT is involved in a myriad of physio-pathological cellular processes, three main different types of EMT have been described, particularly those: (1) Occurring during embryogenesis, (2) occurring during chronic fibrotic pathologies, and (3) taking place during tumor progression [26]. The first type is essential for physiologic implantation, development, and embryogenesis. The second type occurs during chronic inflammatory-fibrotic pathologies and is associated with fibrosis and organ 
dysfunction. The third type is characteristic of carcinomas, i.e., cells that have already undergone rounds of genetic-epigenetic changes and show substantial alterations in proliferation/cell death mechanisms.

Thus, tumor-related EMT is now considered one of the primary mechanisms of tumor progression [13]. This process has some specificities concerning other forms of EMT: For instance, cancer cells most often undergo an incomplete or partial EMT [26]. Also, EMT features may be acquired by non-epithelial tumors, such as sarcomas. Similarly to nontumor cells, the induction of the EMT program is promoted by the expression of EMT-TFs $[27,28]$. Interestingly, although genetic alterations are always present in tumors, EMT-TFs are rarely mutated in cancers.

Cells under EMT have enhanced motility and invasiveness, allowing them to break the basal lamina and reach the stromal areas, which are rich in hematic and lymphatic vessels. The increased migration-invasion is mediated by the formation of invadopodia, which are actin-rich protrusions expressing at the cell edges gelatinases or matrix metalloproteases (MMPs), such as Membrane type 1 (MT1)-MMP or MMP2/MMP9. Epithelial cells generally do not express these enzymes, which can degrade the ECM, and their acquisition is a critical step towards a malignant phenotype.

Tumor cells undergoing EMT generally produce an increased amount of ECM proteins, such as collagens, Fibronectin (FN), and vitronectin, and often cooperate with the cells of the local niche (such as cancer-associated fibroblasts, (CAFs), and tumor-associated macrophages, (TAM)) to remodel surrounding tissues to facilitate angiogenesis and cellular invasion, and to modulate local immunity. Besides facilitating invasion and metastasis, EMT in tumors increases survival and chemoresistance. EMT induction allows tumor cells to escape anoikis (death upon cell detachment) and to survive while flowing through hematic and lymphatic vessels, promoting metastasis. This process is generally related to the repositioning of an invading tumor cell to a new proper niche and is often associated with the rescue of an epithelial-like phenotype, a process called mesenchymal to epithelial transition (MET). MET induction is mediated by the different ECM composition of the new niche but also by local soluble factors. Chemoresistance is related to the expression of EMT-TFs involved in the survival of the cells, such as Snail-1, -TWIST1, and ZEB1, even in the absence of increased invasive/metastatic abilities [29]. To this respect, tumor cells undergoing EMT may acquire a profile similar to that of cancer stem cells (CSC). However, the relationship between EMT and stemness is still unclear [13].

Thus, since the EMT process is crucial for cancer-enhanced invasion, metastasis, chemoresistance, and survival, it is now the target of different experimental therapeutic approaches [3-5]. However, even though the role of EMT in the pathogenesis of cancer transformation has been proven in vitro and in vivo, its translation to the clinic has failed in most cases. One possible explanation may reside in the lack the optimal systems for delivery of therapies targeting EMT. In this review, the recent applications of nanomaterials to target EMT in cancer will be discussed. 


\section{Nanomedicine in Cancer Therapy}

The recent advances in nanotechnology offer many tools to fight cancer, which can be exploited to bypass the difficulties usually encountered with traditional drugs [30]. For instance, nanostructures can be used as nanocarriers, which may passively accumulate in weak blood vessels, typical of tumor tissues, due to the well-known enhanced permeability and retention effect (EPR) [31] (Figure 3). Nanocarriers can also be conjugated with molecules with selective binding capabilities, exploiting active targeting mechanisms [32] to improve further the selectivity of the therapy. Besides, nanocarriers can be employed to improve the pharmacokinetic and pharmacodynamic properties of drugs, thus, improving their therapeutic efficacy [31,33]. Moreover, the release of the therapeutic molecules may be regulated by internal stimuli at the target sites, such as $\mathrm{pH}$, redox potential, ionic strength, enzymes, and other stresses [34], or external stimuli, such as temperature, light, ultrasound, magnetic force, and electric fields [34]. These strategies can be exploited to increase the selectivity of the system, decreasing the undesirable effects of the drugs [35]. Also, nanomaterials can have a cytotoxic activity by themselves, and/or increase the efficacy of standard chemotherapies.

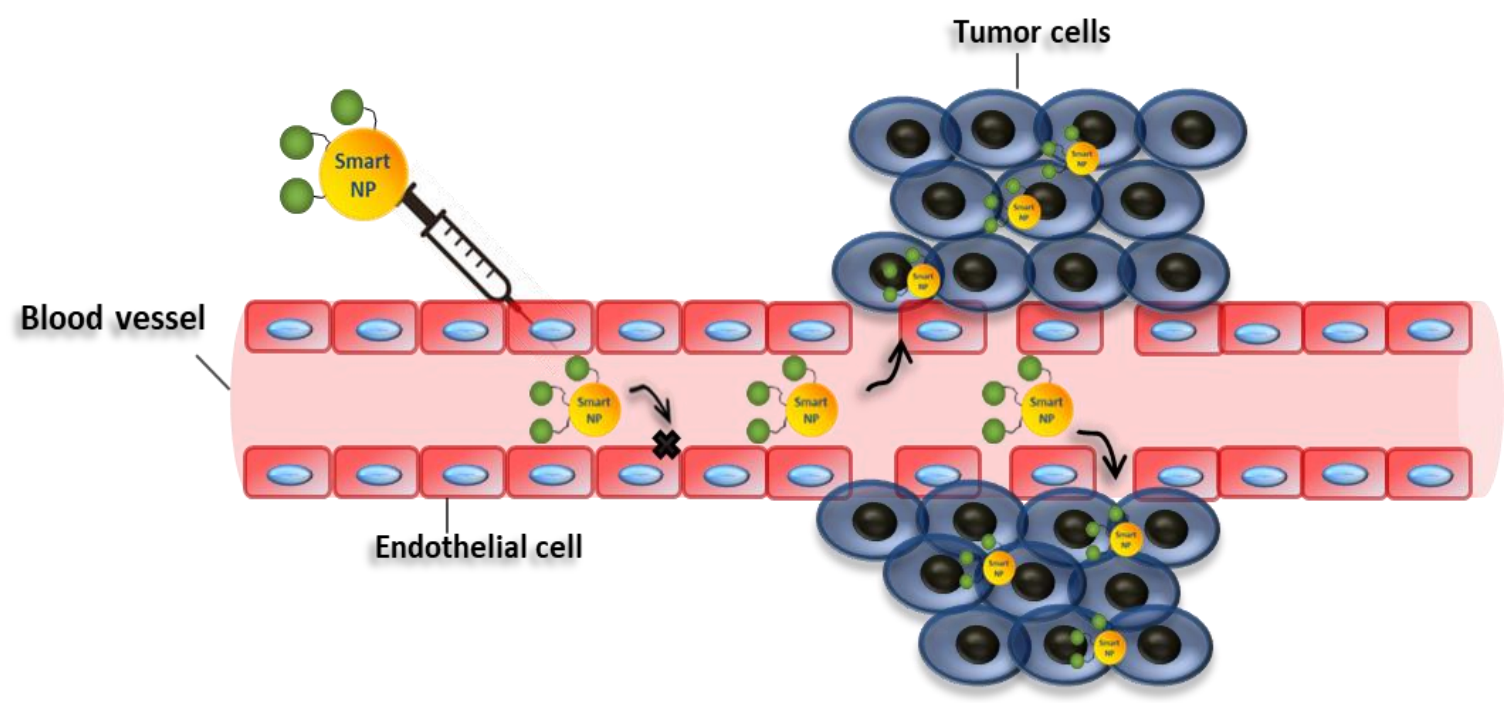

Figure 3. Enhanced permeability and retention effect. Schematic representation showing enhanced permeability and retention of nanoparticles in tumor vessels. Smart nanoparticles can passively accumulate in weak blood vessels, typical of tumor tissues. In this case, drug may be released in the extracellular matrix and then diffuse through the tissue.

Depending on their structural and chemical-physical properties, nanomaterials are divided into several classes, such as liposomes, carbon-based, polymers, metals, metals oxide, and ceramics. In most cases, these nanomaterials are employed as nanocarriers to release therapeutic molecules, such as drugs, proteins, or nucleic acids [36-47].

\section{Targeting EMT with Nanoparticles for Cancer Therapy}

In this section, we comment on the recent studies describing the ability of nanomaterials to inhibit the EMT process in cancer cells, which can be employed to modulate several key features such as migratory/invasive capabilities, stem cell phenotype, and tumor progression (Table 1). 
Table 1. Nanoparticles (NP)-mediated EMT modulation in cancer cells.

\begin{tabular}{|c|c|c|c|c|c|c|c|}
\hline Entry & NPs & Combined Treatments & Target Cells & Cancer Tissues & Regulation of EMT Markers & Biological Effects & Refs \\
\hline 1 & Gold nanoparticles & none & $\begin{array}{l}\text { A2780, } \\
\text { OVCAR5 } \\
\text { SKOV3-ip }\end{array}$ & $\begin{array}{l}\text { Epithelial ovarian } \\
\text { cancer }\end{array}$ & $\begin{array}{c}\text { E-cadherin } \uparrow \\
\text { N-cadherin } \downarrow \\
\text { Snail } \downarrow \\
\text { p42/44 } \downarrow \\
\text { MAPK } \downarrow\end{array}$ & $\begin{array}{l}\text { Inhibition of cell proliferation; } \\
\text { Reversion of epithelial plasticity; } \\
\text { Inhibition of EMT }\end{array}$ & [48] \\
\hline 2 & Gold nanoparticles & none & $\begin{array}{l}\text { A2780, } \\
\text { OVCAR5 and SKOV3-ip }\end{array}$ & $\begin{array}{l}\text { Epithelial ovarian } \\
\text { cancer }\end{array}$ & $\begin{array}{c}\text { ALDH1 } \downarrow, C D 44 \downarrow, C D 133 \downarrow, \text { Sox } \downarrow \downarrow \text {, } \\
\text { MDR1 } \downarrow, \text { ABCG2 } \downarrow \\
\text { Akt signaling } \downarrow \\
\text { NF-kB signaling } \downarrow \\
\text { E-Cadherin } \uparrow \\
\beta \text {-Catenin } \uparrow \\
\text { Vimentin } \downarrow \\
\alpha-S M A \downarrow\end{array}$ & $\begin{array}{l}\text { Sensitivity to cisplatin; } \\
\text { Suppression cancer stem cell } \\
\text { proprieties; } \\
\text { Inhibition of EMT }\end{array}$ & [49] \\
\hline 3 & Gold nanoparticles & none & PANC-1, AsPC-1 and HPAF II & Pancreatic cancer & $\begin{array}{l}\text { E-cadherin } \uparrow \\
\text { N-cadherin } \downarrow \\
\text { Vimentin } \downarrow\end{array}$ & $\begin{array}{l}\text { Sensitivity to gemcitabine; } \\
\text { Suppression cancer stem cell } \\
\text { proprieties; } \\
\text { Inhibition of EMT }\end{array}$ & {$[50]$} \\
\hline 4 & Gold nanoparticles & none & $\begin{array}{l}\text { HUVECs } \\
\text { B16F10 }\end{array}$ & $\begin{array}{l}\text { Melanoma } \\
\text { Blood vessels }\end{array}$ & 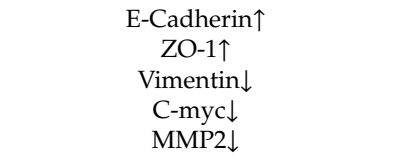 & $\begin{array}{l}\text { Inhibition of cell migration; } \\
\text { Inhibition of EMT }\end{array}$ & [51] \\
\hline 5 & Gold nanorods & none & $\begin{array}{l}\text { HeLA } \\
\text { MCF-7 }\end{array}$ & $\begin{array}{l}\text { Cervical cancer } \\
\text { Breast cancer }\end{array}$ & $\begin{array}{l}\text { Vimentin } \downarrow \\
\text { N-cadherin } \downarrow\end{array}$ & $\begin{array}{l}\text { Inhibition of collective migration; } \\
\text { Decrease of EMT markers }\end{array}$ & [52] \\
\hline 6 & $\begin{array}{c}\text { Gold } \\
\text { Nanoparticles }\end{array}$ & Cold plasma & $\begin{array}{l}\text { T98G } \\
\text { A459 }\end{array}$ & $\begin{array}{l}\text { Glioblastoma } \\
\text { Lung cancer }\end{array}$ & $\begin{array}{c}\text { E-Cadherin } \uparrow \\
\text { N-Cadherin } \downarrow \\
\text { Slug } \downarrow \\
\text { ZEB1 } \downarrow \\
\text { PI3K/AKT patwhay } \downarrow\end{array}$ & $\begin{array}{c}\text { Apoptosis; } \\
\text { Reduction of cell proliferation; } \\
\text { Inhibition of EMT; } \\
\text { Decrease in sphere formation; } \\
\text { Decrease in self-renewal capacity }\end{array}$ & [53] \\
\hline 7 & Titanium dioxide & none & A459 & $\begin{array}{l}\text { Epithelial lung } \\
\text { cancer }\end{array}$ & 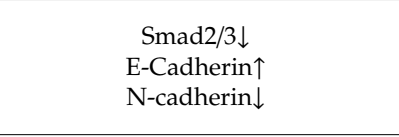 & $\begin{array}{l}\text { Inhibition of TGF- } \beta \text {-Mediated Cell } \\
\text { Migration; } \\
\text { Suppression of TGF- } \beta \text {-Induced EMT; } \\
\text { Attenuation of TGF- } \beta \text { Signaling }\end{array}$ & {$[54]$} \\
\hline 8 & $\begin{array}{l}\text { Titanium dioxide } \\
\text { Silicon dioxide }\end{array}$ & none & LX-2 & Fibrosis & $\begin{array}{l}\text { N-Cadherin } \downarrow \\
\text { E-Cadherin } \uparrow\end{array}$ & $\begin{array}{c}\text { Inhibition of EMT; } \\
\text { Inhibition of fibrosis; } \\
\text { Reduction of adhesion and migration } \\
\text { profiles }\end{array}$ & [55] \\
\hline 9 & $\begin{array}{c}\mathrm{ZnO} \\
\text { Nanostructures }\end{array}$ & none & $\begin{array}{l}\text { T98G } \\
\text { SNU-80 } \\
\text { H-460 }\end{array}$ & $\begin{array}{l}\text { Glioblastoma } \\
\text { Thyroid cancer } \\
\text { Lung cancer }\end{array}$ & $\begin{array}{l}\text { N-Cadherin } \downarrow \\
\quad \text { ZEB1 } \downarrow\end{array}$ & $\begin{array}{c}\text { Cell death; } \\
\text { Apoptosis; } \\
\text { Reduction of cell invasion; } \\
\text { Inhibition of EMT }\end{array}$ & {$[56]$} \\
\hline
\end{tabular}


Table 1. Cont.

\begin{tabular}{|c|c|c|c|c|c|c|c|}
\hline Entry & NPs & Combined Treatments & Target Cells & Cancer Tissues & Regulation of EMT Markers & Biological Effects & Refs \\
\hline 10 & $\begin{array}{c}\text { D, } \\
\text { L-lactic-co-glycolic } \\
\text { acid (PLGA) }\end{array}$ & $\alpha$-Mangostin & $\begin{array}{c}\text { PANC-1, AsPC-1, MIA PaCa-2; } \\
\text { Human CSCs, } \\
\text { Kras } 12 \mathrm{D} \text { mouse } \\
\text { CSCs }\end{array}$ & Pancreatic cancer & $\begin{array}{c}\text { E-cadherin } \uparrow \\
\text { N-cadherin } \downarrow \\
\text { Slug, Snail1, ZEB1 } \downarrow \\
\text { Nanog, c-Myc, Oct4 } \downarrow \\
\text { Shh pathway } \downarrow \\
\text { Gli targets } \downarrow \\
\end{array}$ & $\begin{array}{c}\text { Inhibition of cancer growth; } \\
\text { development; metastasis; inhibition of } \\
\text { pluripotency; } \\
\text { Inhibition of EMT }\end{array}$ & [57] \\
\hline 11 & $\begin{array}{c}\text { D, } \\
\text { L-lactic-co-glycolic } \\
\text { acid (PLGA) }\end{array}$ & Anthothecol & $\begin{array}{c}\text { PANC-1, AsPC-1, MIA PaCa-2; } \\
\text { Human CSCs, } \\
\text { KrasG12D mouse } \\
\text { CSCs }\end{array}$ & Pancreatic cancer & $\begin{array}{c}\text { E-cadherin } \uparrow \\
\text { N-cadherin } \downarrow \\
\text { Slug, Snail, ZEB1 } \downarrow \\
\text { Nanog, c-Myc, Oct4 } \downarrow \\
\text { Shh pathway } \downarrow \\
\text { Gli targets } \downarrow\end{array}$ & $\begin{array}{l}\text { Inhibition of cell proliferation; invasion; } \\
\text { migration; induction of apoptosis; } \\
\text { inhibition of pluripotency; } \\
\text { Inhibition of EMT }\end{array}$ & {$[58]$} \\
\hline 12 & $\begin{array}{c}\text { D, } \\
\text { L-lactic-co-glycolic } \\
\text { acid (PLGA }\end{array}$ & Wedelolactone & $\begin{array}{l}\text { MDA-MB-231 } \\
\text { Breast cancer stem cells }\end{array}$ & $\begin{array}{l}\text { Triple negative } \\
\text { breast cancer }\end{array}$ & $\begin{array}{c}\text { E-Cadherin } \uparrow \\
\text { N-Cadherin } \downarrow \\
\text { TWIST1 } \downarrow \\
\text { Snail } \downarrow \\
\text { Vimentin } \downarrow\end{array}$ & $\begin{array}{c}\text { Retarded migration and invasion; } \\
\text { Reduction of cell viability; } \\
\text { Apoptosis; } \\
\text { Inhibition of EMT; } \\
\text { Reduction of pluripotency; } \\
\text { Drug sensitivity to paclitaxel } \\
\end{array}$ & [59] \\
\hline 13 & $\begin{array}{c}\text { D, } \\
\text { L-lactic-co-glycolic } \\
\text { acid (PLGA) }\end{array}$ & Salinomycin & AsPC-1 & Pancreatic cancer & $\begin{array}{c}\text { E-Cadherin } \uparrow \\
\beta \text { catenin } \uparrow \\
\text { TGF } \beta \text { R- } 1 \downarrow \\
\text { TGF } \beta \text { R- } 2 \downarrow \\
\end{array}$ & $\begin{array}{l}\text { Inhibition of EMT; } \\
\text { Apoptosis }\end{array}$ & [60] \\
\hline 14 & Polymeric micelles & Salinomycin & A459 & Lung cancer & Vimentin $\downarrow$ & $\begin{array}{c}\text { Inhbition of EMT; } \\
\text { Reversion to epithelial phenotype; } \\
\text { Reduction of cell migration; } \\
\text { Prevention of P-gp efflux }\end{array}$ & [61] \\
\hline 15 & $\begin{array}{c}\text { Silver } \\
\text { nanoparticles }\end{array}$ & Gallic Acid & A459 & Lung cancer & $\begin{array}{c}\text { Vimentin } \downarrow \\
\text { N-cadherin } \downarrow \\
\text { Snail1 } \downarrow \\
\text { E-cadherin } \uparrow \\
\end{array}$ & $\begin{array}{l}\text { Loss of radiation-induced metastasis; } \\
\text { Inhibition of EMT }\end{array}$ & [62] \\
\hline 16 & $\begin{array}{l}\text { Curcumin loaded } \\
\text { selenium } \\
\text { nanoparticles } \\
\text { (Se-Cu NPs) }\end{array}$ & Curcumin & HCT116 & Colon cancer & $\begin{array}{c}\text { CD44 } \downarrow \\
\text { N-Cadherin } \downarrow\end{array}$ & $\begin{array}{l}\text { Induction of autophagy; } \\
\text { Induction of apoptosis; } \\
\text { Induction of cell cycle arrest; } \\
\text { Inhibition of EMT }\end{array}$ & [63] \\
\hline 17 & $\begin{array}{l}\text { Curcumin loaded } \\
\text { selenium } \\
\text { nanoparticles } \\
\text { (Se-Cu NPs); } \\
\text { CD44-targeted } \\
\text { DOX loaded } \\
\text { nanoparticles } \\
\text { (PSHA-DOXNPs) }\end{array}$ & $\begin{array}{l}\text { Curcumin, } \\
\text { Doxorubicin }\end{array}$ & HCT116 & Colon cancer & $\begin{array}{c}\text { N-Cadherin } \downarrow \\
\text { Vimentin } \downarrow \\
\text { Snail1 } \downarrow \\
\text { CD44 } \downarrow \\
\text { MMP2 } \downarrow \\
\text { MMP4 } \downarrow\end{array}$ & $\begin{array}{c}\text { Induction ROS levels; } \\
\text { Decreased mitochondrial membrane } \\
\text { potential; } \\
\text { Induction cell cycle arrest; } \\
\text { Apoptosis; } \\
\text { Inhibition of EMT }\end{array}$ & [64] \\
\hline
\end{tabular}


Table 1. Cont

\begin{tabular}{|c|c|c|c|c|c|c|c|}
\hline Entry & NPs & Combined Treatments & Target Cells & Cancer Tissues & Regulation of EMT Markers & Biological Effects & Refs \\
\hline 18 & $\begin{array}{c}\text { Gold } \\
\text { Nanoparticles }\end{array}$ & Quercetin & $\begin{array}{l}\text { MCF-7 } \\
\text { MDA-MB-231 } \\
\text { HUVECs }\end{array}$ & Breast cancer & $\begin{array}{c}\text { E-Cadherin } \uparrow \\
\text { N-Cadherin } \downarrow \\
\text { Vimentin } \downarrow \\
\text { Snail } \downarrow \\
\text { Slug } \downarrow \\
\text { TWIST1 } \downarrow \\
\text { MMP2/9 } \downarrow \\
\text { EGFR/VEGFR-2 signalling } \downarrow\end{array}$ & $\begin{array}{l}\text { Inhibition of EMT; } \\
\text { Inhibition of angiogenesis; } \\
\text { Inhibition of cell invasion }\end{array}$ & [65] \\
\hline 19 & Liposomal & Quercetin & Eca109/9706 & $\begin{array}{l}\text { Esophageal } \\
\text { squamous cell } \\
\text { carcinoma }\end{array}$ & E-Cadherin $\uparrow$ & $\begin{array}{c}\text { Apoptosis; } \\
\text { Inhibition of EMT }\end{array}$ & {$[66]$} \\
\hline 20 & $\begin{array}{l}\text { Mesoporous silica; } \\
\text { PEG-PLA micelles }\end{array}$ & $\begin{array}{l}\text { Epigallocatechin } \\
\text { gallate/iron }\end{array}$ & $4 \mathrm{~T} 1$ & $\begin{array}{l}\text { Mouse breast } \\
\text { cancer }\end{array}$ & $\begin{array}{c}\text { MMP2/9 } \downarrow \\
\text { VEGF } \downarrow \\
\text { Vimentin } \downarrow \\
\text { E-cadherin } \uparrow\end{array}$ & $\begin{array}{l}\text { Suppression of metastasis; } \\
\text { Inhibition of EMT }\end{array}$ & [67] \\
\hline 21 & $\begin{array}{l}\text { Layered double } \\
\text { hydroxide }\end{array}$ & Etoposide & $\begin{array}{l}\text { U87MG } \\
\text { Glioblastoma stem cells (GSCs) }\end{array}$ & Glioblastoma & $\begin{array}{c}\text { Sox } 2 \downarrow \\
\text { Oct4 } \downarrow \\
\text { Nanog } \downarrow \\
\text { Nestin } \downarrow \\
\text { Snail } \downarrow \\
\text { N-Cadherin } \downarrow \\
\text { E-Cadherin } \uparrow \\
\text { PI3K/AKT/mTOR } \downarrow \\
\text { WNT/GSK3 } \beta / \beta \text {-catenin } \uparrow\end{array}$ & $\begin{array}{l}\text { Inhibition of cell proliferation; } \\
\text { Down-regulation of GSCs stemness; } \\
\text { Inhbition of EMT }\end{array}$ & [68] \\
\hline 22 & Liposomes & $\begin{array}{l}\text { ADH-1 peptide } \\
\text { Paclitaxel }\end{array}$ & MCF7-paclitaxel resistant & Breast cancer & $\begin{array}{l}\text { N-Cadherin } \downarrow \\
\text { E-Cadherin } \uparrow\end{array}$ & $\begin{array}{l}\text { Improvement of chemosensitivity; } \\
\text { Inhibition of cell migration; } \\
\text { Inhibition of EMT }\end{array}$ & [69] \\
\hline 23 & Liposomes & $\begin{array}{l}\text { ADH-1 peptide } \\
\text { DOX } \\
\text { Hyaluronic Acid }\end{array}$ & A459 & Lung cancer & $\begin{array}{l}\text { N-Cadherin } \downarrow \\
\text { CD44 } \downarrow\end{array}$ & $\begin{array}{l}\text { Drug sensitivity; } \\
\text { Reduction of cell migration; } \\
\text { Inhibition of EMT }\end{array}$ & {$[70,71]$} \\
\hline 24 & Gold nanoparticles & $\begin{array}{l}\text { Dexamethasone (DSH) } \\
\text { thiol derivative } \\
\text { Withaferin (WFA) }\end{array}$ & B16F10 & Murine melanoma & $\begin{array}{c}\text { E-Cadherin } \uparrow \\
\text { Vimentin } \downarrow \\
\text { pAKT/AKT signalling } \downarrow\end{array}$ & $\begin{array}{l}\text { Induction of apoptosis; } \\
\text { Inhibition of cell cycle; } \\
\text { Induction of MET; } \\
\text { Inhibition of EMT }\end{array}$ & [72] \\
\hline 25 & Zinc arsenite & Arsenic trioxide & $\begin{array}{c}\text { Hep3b, HepG2, Bel7402 and } \\
\text { MHCC } 97 \mathrm{~L}\end{array}$ & Liver cancer & $\begin{array}{c}\text { E-Cadherin } \uparrow \\
\text { Vimentin } \downarrow \\
\text { Slug } \downarrow \\
\text { SHP-1/JAK2/STAT3 } \downarrow\end{array}$ & $\begin{array}{l}\text { Suppress tumor initiation and growth; } \\
\text { Suppression metastasis } \\
\text { Inhibition stemness and EMT }\end{array}$ & [73] \\
\hline
\end{tabular}


Table 1. Cont

\begin{tabular}{|c|c|c|c|c|c|c|c|}
\hline Entry & NPs & Combined Treatments & Target Cells & Cancer Tissues & Regulation of EMT Markers & Biological Effects & Refs \\
\hline 26 & $\begin{array}{c}\text { Albumin based } \\
\text { nanoparticles }\end{array}$ & Arsenic trioxide & $\begin{array}{l}\text { in 5-8F } \\
\text { CNE-2 }\end{array}$ & $\begin{array}{l}\text { Nasopharyngeal } \\
\text { carcinoma }\end{array}$ & $\begin{array}{l}\text { E-Cadherin } \uparrow \\
\text { N-Cadherin } \downarrow \\
\text { Vimentin } \downarrow\end{array}$ & $\begin{array}{l}\text { Inhibition of colony formation; } \\
\text { Inhibition of cell invasion; } \\
\text { Inhibition of EMT }\end{array}$ & [74] \\
\hline 27 & Liposome & ${ }^{188} \operatorname{Re}$ & ES-2-luc & Ovarian cancer & $\begin{array}{l}\text { E-Cadherin } \uparrow \\
\text { Vimentin } \downarrow \\
\quad \text { p53 } \uparrow\end{array}$ & $\begin{array}{c}\text { Switch to mitochondrial } \\
\text { phosphorylation; Reactivation of p53 } \\
\text { function; } \\
\text { Inhibition of EMT }\end{array}$ & [75] \\
\hline 28 & Liposome & ${ }^{188} \mathrm{Re}$ & $\mathrm{FaDu}$ & $\begin{array}{l}\text { Head and neck } \\
\text { squamous cell } \\
\text { carcinoma }\end{array}$ & Let-7 $\uparrow$ & Suppression of tumor growth & [76] \\
\hline 29 & Liposome & ${ }^{188} \operatorname{Re}$ & $\begin{array}{l}\text { FaDu, } \\
\text { SAS }\end{array}$ & $\begin{array}{l}\text { Head and neck } \\
\text { squamous cell } \\
\text { carcinoma }\end{array}$ & $\begin{array}{c}\text { E-Cadherin } \uparrow \\
\text { N-Cadherin } \downarrow \\
\text { TWIST1/2 } \downarrow \\
\text { Vimentin } \downarrow \\
\text { ZEB1 } \downarrow \\
\text { Slugs } \downarrow \\
\end{array}$ & $\begin{array}{l}\text { Inhibition of cell proliferation; } \\
\text { Cell death; } \\
\text { Inhibition of EMT }\end{array}$ & [77] \\
\hline 30 & Liposome & Simvastatin, Paxicitel & $\begin{array}{c}\text { A549T } \\
\text { PC9 } \\
\text { TAM (tumor associated } \\
\text { macrophages) }\end{array}$ & $\begin{array}{l}\text { Lung and prostate } \\
\text { cancer }\end{array}$ & $\begin{array}{c}\text { FAK } \downarrow \\
\text { ERK/AKT } \downarrow \\
\text { TNF- } \alpha \uparrow \\
\text { TGF } \beta \downarrow \\
\text { LXR/ABCA1 } 1 \\
\text { E-Cadherin } \uparrow \\
\text { Vimentin } \downarrow\end{array}$ & $\begin{array}{c}\text { Inhibition of EMT; } \\
\text { Sensitization to paxicitel; } \\
\text { Repolarization of TAM; } \\
\text { Regulation of cholesterol metabolism }\end{array}$ & [78] \\
\hline 31 & $\begin{array}{l}\text { Carboxymethyl } \\
\text { dextran } \\
\text { (CMD)-chitosan } \\
\text { nanoparticles } \\
\text { (ChNPs) }\end{array}$ & $\begin{array}{l}\text { Snail siRNA } \\
\text { DOX }\end{array}$ & HCT-116 & Colon cancer & $\begin{array}{c}\text { MMP9 } \downarrow \\
\text { Vimentin } \downarrow \\
\text { E-cadherin } \uparrow\end{array}$ & $\begin{array}{l}\text { Inhibition cell growth; apoptosis; } \\
\text { inhibition of migration; } \\
\text { Inhibition of EMT }\end{array}$ & [79] \\
\hline 32 & $\begin{array}{l}\text { Carboxymethyl } \\
\text { dextran } \\
\text { (CMD)-chitosan } \\
\text { nanoparticles } \\
\text { (ChNPs) }\end{array}$ & $\begin{array}{l}\text { Snail siRNA } \\
\text { SN38 }\end{array}$ & PC-3 & Prostate cancer & $\begin{array}{c}\text { E-cadherin } \uparrow \\
\text { Claudin- } 1 \uparrow\end{array}$ & $\begin{array}{l}\text { Reduction of cell proliferation; } \\
\text { Reduction of cell migration; Inhibition } \\
\text { of EMT }\end{array}$ & [80] \\
\hline 33 & $\begin{array}{l}\text { Carboxymethyl } \\
\text { dextran } \\
\text { (CMD)-chitosan } \\
\text { nanoparticles } \\
\text { (ChNPs) }\end{array}$ & $\begin{array}{l}\text { Snail siRNA } \\
\text { HMGA2 siRNA } \\
\text { DOX }\end{array}$ & A459 & Lung cancer & $\begin{array}{c}\text { HMGA2 } \downarrow \\
\text { E-cadherin } \uparrow \\
\text { Vimentin } \downarrow \\
\text { MMP9 } \downarrow\end{array}$ & $\begin{array}{c}\text { Apoptosis; } \\
\text { Reduction in cell migration; } \\
\text { Drug sensitivity; } \\
\text { Inhibition of EMT }\end{array}$ & [81] \\
\hline
\end{tabular}


Table 1. Cont

\begin{tabular}{|c|c|c|c|c|c|c|c|}
\hline Entry & NPs & Combined Treatments & Target Cells & Cancer Tissues & Regulation of EMT Markers & Biological Effects & Refs \\
\hline 34 & $\begin{array}{c}\text { Polypeptide } \\
\text { micelles } \\
\text { (PEG-PLL-PLLeu) }\end{array}$ & $\begin{array}{l}\text { ZEB1 siRNA } \\
\text { DOX }\end{array}$ & $\mathrm{H} 460$ & $\begin{array}{l}\text { Non-small cell } \\
\text { lung cancer } \\
\text { (NSCLC) }\end{array}$ & $\begin{array}{c}\text { ZEB1 } \downarrow \\
\text { E-cadherin } \uparrow \\
\text { SOX2 } \\
\text { ABCG2 } \downarrow\end{array}$ & $\begin{array}{l}\text { Inhibition of EMT; } \\
\text { Repression of CSC properties; } \\
\text { Reduction of cell invasion; } \\
\text { Sensitivity to DOX }\end{array}$ & [82] \\
\hline 35 & $\begin{array}{c}\text { Polyamidoamine } \\
\text { dendrimers } \\
\text { (PAMAM) and } \\
\text { Hyaluronic-acid } \\
\text { conjugated } \\
\text { mesoporous silica } \\
\text { nanoparticles } \\
\text { (MSN-Has) }\end{array}$ & $\begin{array}{l}\text { TWIST1 siRNA } \\
\text { Cisplatin }\end{array}$ & $\begin{array}{c}\mathrm{F} 2 \\
\text { Ovcar8 }\end{array}$ & Ovarian cancer & $\begin{array}{c}\text { Vimentin } \downarrow \\
\text { E-Cadherin } \uparrow \\
\text { N-Cadherin } \downarrow\end{array}$ & $\begin{array}{l}\text { Chemosensitivity to cisplatin; } \\
\text { Inhibition of EMT }\end{array}$ & {$[83,84]$} \\
\hline 36 & Mesoporous Silica & TWIST1 siRNA & MDA-MB-435S & Melanoma & $\begin{array}{l}\text { Vimentin } \downarrow \\
\text { CCL2 } \downarrow\end{array}$ & $\begin{array}{l}\text { Inhibition of migration; } \\
\text { Inhibition of EMT }\end{array}$ & [85] \\
\hline 37 & $\begin{array}{l}\text { Chitosan-coated } \\
\text { nanoparticles }\end{array}$ & TWIST1 siRNA & CNE2 & $\begin{array}{c}\text { Nasopharyngeal } \\
\text { carcinoma }\end{array}$ & $\mathrm{p}$-ERK $\uparrow$ & $\begin{array}{c}\text { Sensitivity to radiation; } \\
\text { Irradiation-induced apoptosis }\end{array}$ & [86] \\
\hline 38 & $\begin{array}{l}\text { Polyamidoamine } \\
\text { dendrimers } \\
\text { (PAMAM) }\end{array}$ & TWIST1 siRNA & SUM1315 & $\begin{array}{l}\text { Triple negative } \\
\text { breast cancer }\end{array}$ & $\begin{array}{l}\text { N-Cadherin } \downarrow \\
\text { Vimentin } \downarrow\end{array}$ & $\begin{array}{l}\text { Reduction of cell migration and } \\
\text { invasion; } \\
\text { Inhibition of EMT }\end{array}$ & [87] \\
\hline 39 & $\begin{array}{l}\text { (PLGA)2-PEI-DMMA } \\
\text { nanoparticles }\end{array}$ & NgBR siRNA & $\begin{array}{c}\text { HUVECs } \\
\text { MDA-MB-231 } \\
\text { 4T1 }\end{array}$ & Breast cancer & $\begin{array}{c}\text { Vimentin } \downarrow \\
\text { E-Cadherin } \uparrow\end{array}$ & $\begin{array}{l}\text { Inhibition of endothelial cell migration; } \\
\text { Suppression of cancer cell invasion } \\
\text { Normalization of tumor blood vessel; } \\
\text { Inhibition of EMT }\end{array}$ & [88] \\
\hline 40 & ECO lipid carrier & $\beta 3$ integrin siRNA & MDA-MB-231 & $\begin{array}{l}\text { Triple negative } \\
\text { breast cancer }\end{array}$ & $\begin{array}{c}\text { PAI- } 1 \downarrow \\
\text { N-cadherin } \downarrow \\
\text { E-cadherin } \uparrow \\
\text { CK19 } \uparrow\end{array}$ & $\begin{array}{c}\text { Inhibition of TGF } \beta \text {-mediated cytostasis; } \\
\text { Inhibition of TGF } \beta \text {-mediated EMT; } \\
\text { Inhibition of TGF } \beta \text {-mediated invasion; } \\
\text { Inhibition of 3-dimensional organoid } \\
\text { growth; } \\
\text { Inhibition of EMT }\end{array}$ & [89] \\
\hline 41 & ECO lipid carrier & DANCR siRNA & $\begin{array}{c}\text { MDA-MB-231 } \\
\text { BT549 }\end{array}$ & $\begin{array}{l}\text { Triple negative } \\
\text { breast cancer }\end{array}$ & $\begin{array}{c}\beta \text {-catenin } \downarrow \\
\text { ZEB1 } \downarrow \\
\text { Stat proteins } \downarrow \\
\text { N-cadherin } \downarrow \\
\text { Survivin } \downarrow \\
\text { WNT signaling } \downarrow\end{array}$ & $\begin{array}{c}\text { Inhibition of cell invasion; } \\
\text { Inhibition of cell migration; } \\
\text { Reduction of survival; } \\
\text { Reduction in tumor spheroid } \\
\text { Formation; } \\
\text { Inhibition of cell proliferation } \\
\text { Inhibition of EMT }\end{array}$ & [90] \\
\hline
\end{tabular}


Table 1. Cont

\begin{tabular}{|c|c|c|c|c|c|c|c|}
\hline Entry & NPs & Combined Treatments & Target Cells & Cancer Tissues & Regulation of EMT Markers & Biological Effects & Refs \\
\hline 42 & $\begin{array}{l}\text { Poly(lactide-co } \\
\text {-glycolide) acid } \\
\text { nanoparticles } \\
\text { (PLGA NPs) }\end{array}$ & DCAMKL-1 siRNA & HCT116 & Colon cancer & $\begin{array}{c}\text { miRNA 200a } \uparrow \\
\text { miRNA let-7a } \uparrow \\
\text { E-Cadherin } \uparrow \\
\text { ZEB1/2 } \downarrow \\
\text { Snail } \downarrow \\
\text { Slug } \downarrow \\
\end{array}$ & $\begin{array}{l}\text { Inhibition of tumor growth; } \\
\text { Inhibition of EMT }\end{array}$ & [91] \\
\hline 43 & $\begin{array}{l}\text { Polyethylene } \\
\text { glycol- } \\
\text { polyethyleneimine } \\
\text {-chlorin e6 } \\
\end{array}$ & Wnt-1 siRNA & $\mathrm{KB}$ & $\begin{array}{l}\text { Oral squamous } \\
\text { cell carcinoma }\end{array}$ & $\begin{array}{c}\text { Wnt-1 } 1 \\
\beta \text {-catenin } \downarrow \\
\text { Vimentin } \downarrow\end{array}$ & $\begin{array}{c}\text { Inhibition of cell growth; sensibility to } \\
\text { PDT; } \\
\text { Inhibition of EMT }\end{array}$ & [92] \\
\hline 44 & $\begin{array}{l}\text { Cationic solid lipid } \\
\text { nanoparticles } \\
\text { (SLN) }\end{array}$ & $\begin{array}{c}\text { STAT3 decoy } \\
\text { oligodeoxynucleotide }\end{array}$ & $\begin{array}{l}\text { A2780 } \\
\text { SKOV3 }\end{array}$ & Ovarian cancer & $\begin{array}{c}\text { E-Cadherin } \uparrow \\
\text { Snail } \downarrow \\
\text { MMP9 } \downarrow\end{array}$ & $\begin{array}{l}\text { Induction of cell death; } \\
\text { Apoptotic and autophagy cell death; } \\
\text { Inhibition of invasion; } \\
\text { Inhibition of EMT }\end{array}$ & [93] \\
\hline 45 & $\begin{array}{c}\text { Gelatin } \\
\text { nanoparticles }\end{array}$ & AXL siRNA & $\begin{array}{l}\mathrm{H} 820 \text { and } \mathrm{H} 1975 \\
\text { erlotinib-resistant }\end{array}$ & $\begin{array}{l}\text { Non-small cell } \\
\text { lung cancer }\end{array}$ & $\begin{array}{c}\text { MMP9 } \downarrow \\
\text { MMP2 } \downarrow \\
\text { Vimentin } \downarrow \\
\text { N-cadherin } \downarrow \\
\end{array}$ & $\begin{array}{l}\text { Overcome of chemoresistance to } \\
\text { tyrosine kinase inhitors; } \\
\text { Inhbition of EMT }\end{array}$ & [94] \\
\hline 46 & $\begin{array}{c}\text { Polyethylene } \\
\text { glycol- } \\
\text {-polyethylenimine- } \\
\text {-magnetic iron } \\
\text { oxide } \\
\text { (PEG-PEI-IONPs) } \\
\end{array}$ & $\begin{array}{l}\text { microRNA-21 antisense } \\
\text { oligonucleotides; } \\
\text { Gemcitabine }\end{array}$ & $\begin{array}{l}\text { PANC-1 } \\
\text { MIA PACA-2 }\end{array}$ & Pancreatic cancer & $\begin{array}{c}\text { PTEN } \uparrow \\
\text { PDCD4 } \uparrow \\
\text { Vimentin } \downarrow \\
\text { E-Cadherin } \uparrow\end{array}$ & $\begin{array}{c}\text { Inhibition of cell proliferation; } \\
\text { Apoptosis; } \\
\text { Inhibition of invasion and cell } \\
\text { migration; } \\
\text { Inhibition of EMT }\end{array}$ & [95] \\
\hline 47 & $\begin{array}{l}\text { Lipid-polymer } \\
\text { hybrid } \\
\text { nanoparticles } \\
\text { modified with CPP }\end{array}$ & $\begin{array}{l}\text { Afatinib; } \\
\text { miR-139 }\end{array}$ & Caco-2 & Colorectal cancer & $\begin{array}{c}\text { E-Cadherin } \uparrow \\
\beta \text {-catenin } \downarrow \\
\text { Slug } \downarrow\end{array}$ & $\begin{array}{c}\text { Inhbition of EMT; } \\
\text { Sensitivity to afatinib; } \\
\text { Reduced cancer cell migration }\end{array}$ & [96] \\
\hline 48 & $\begin{array}{l}\text { Gelatinases-stimuli } \\
\text { poly(ethylene } \\
\text { glycol) } \\
\text {-peptide-poly } \\
\text { (E-caprolactone) } \\
\text { copolymer }\end{array}$ & $\begin{array}{l}\text { miR-200c } \\
\text { Docetaxel }\end{array}$ & $\begin{array}{c}\text { BGC-823 } \\
\text { CSCs and non-CSCs }\end{array}$ & $\begin{array}{c}\text { Gastric } \\
\text { adenocarcinoma }\end{array}$ & $\begin{array}{l}\text { E-Cadherin } \uparrow \\
\text { CD44 } \downarrow\end{array}$ & $\begin{array}{l}\text { Drug sensitivity to DOC; } \\
\text { Inhibition of EMT }\end{array}$ & [97] \\
\hline
\end{tabular}




\subsection{Modulating EMT with Unmodified Nanomaterials}

In addition to the advantages of using nanomaterials as nanocarriers [98,99], their inherent properties can also be exploited for therapeutic purposes. In this sense, gold and metal oxide nanoparticles have shown remarkable capabilities in the inhibition of the EMT process.

\subsubsection{Gold Nanoparticles}

Gold nanoparticles (AuNPs) have been largely exploited in biomedicine as drug delivery systems, because of their low toxicity, biocompatibility, and stability [100]. In this regard, the surface of AuNPs can be modified with a variety of bioactive molecules, such as chemotherapy drugs, nucleic acids, and proteins.

It has been reported that unmodified AuNPs inhibit cell proliferation and metastasis and enhance the sensitivity to cisplatin and gemcitabine in in vitro and in vivo models of pancreatic and ovarian cancer by reverting the mesenchymal phenotype of cancer cells to the epithelial one [48-50]. This occurs by reducing the expression of key stem cell markers as well as EMT-related markers and by preventing the activation of Akt, NF-kB, and MAPK signaling axis, which are crucial for EMT, stemness, and drug resistance [48-50].

Another study revealed that AuNPs treatment was able to downregulate EMT in melanoma tumors by reducing the expression of some EMT proteins such as vimentin, E-cadherin, and MMP2 [51]. Consequently to EMT modulation, these nanomaterials lead the normalization of the tumor vasculature, mitigate the hypoxia in melanoma tumor, suppress the migration of Human umbilical vein endothelial cells (HUVECs) and B16F10 cells, and decrease melanoma tumor metastasis in vivo [51]. Besides, the inherent properties of metallic nanoparticles can be exploited for hyperthermia-based approaches [101], where body tissues undergo high temperatures to injure cancer cells or to sensitize them to chemo/radiotherapy. In this regard, hyperthermia has been shown to inhibit EMT in tongue squamous cell carcinoma [102], pancreatic adenocarcinoma cells [103,104], and hepatocellular carcinoma [105,106], resulting in inhibition of cancer cell invasion and sensitizing gemcitabine-resistant pancreatic adenocarcinoma cells to gemcitabine.

In the case of metallic nanoparticles, it is possible to produce local heating at the nanoparticle-containing cells without hurting the neighboring healthy tissues, when irradiated by a laser at a wavelength near their plasmon-resonant absorption band [107]. In this regard, gold nanorods (AuNRs) have been used in plasmonic photothermal therapy (PPTT) to block EMT, leading to a significant reduction in cancer cell collective migration [52].

Another study reported that the combined treatment of Polyethylene glycol (PEG)-coated AuNPs and PPTT was able to inhibit EMT by preventing the activation of the PI3K/Akt pathway in glioblastoma and lung cancer cells [53]. This co-treatment also suppressed tumor growth in xenograft mice models, indicating a direct link between EMT and cell death in solid tumors [53]. 


\subsubsection{Metal Oxide Nanoparticles}

Titanium dioxide nanoparticles $\left(\mathrm{TiO}_{2} \mathrm{NPs}\right)$ have been exploited to deliver a variety of therapeutic molecules, including chemicals, antibodies, or modified nucleic acids for cancer therapy [108]. A recent study revealed that $\mathrm{TiO}_{2} \mathrm{NPs}$ suppress the EMT process by blocking TGF $\beta$ signaling in cancer epithelial cells, leading to inhibition of cell migration without exhibiting cytotoxicity [54].

In particular, $\mathrm{TiO}_{2} \mathrm{NPs}$ induce lysosomal degradation of the TGF $\beta$ receptor complex (T $\beta \mathrm{RI} / \mathrm{II}$ ), and thereby downregulate the expression of TGF $\beta$-target genes. $\mathrm{TiO}_{2} \mathrm{NPs}$ and silicon dioxide $\left(\mathrm{SiO}_{2} \mathrm{NPs}\right)$ were able to suppress ECM production, blocking the effect of TGF $\beta$ in cells implicated in liver fibrosis [55].

Zinc oxide nanostructures (ZnO-NSts), such as nanoplates (NPls), nanorods (NRs), nanosheets (NSs), and nanoflowers (NFs) have shown to play a role in the control of cancer growth and apoptosis, but the mechanisms implicated remain unclear $[109,110]$.

In this regard, a novel study reports that these ZnO-NSts nanostructures downregulate EMT markers exerting cytotoxic effect against glioblastoma, lung, and thyroid cancer cells [56]. The inhibition of the mesenchymal phenotype by these drugs led to the suppression of cancer invasiveness and the induction of cell death due to oxidative stress and caspase-dependent pathways [56].

Hence, unmodified metal oxide nanostructures could help the control of cancer growth and metastasis by regulating EMT and represent a new promising therapeutic tool.

\subsection{Delivery of Small Molecules to Inhibit EMT}

A variety of nanoparticles have been successfully employed to deliver small molecules, such as natural products and/or synthetic drugs, to suppress or reverse EMT via the inhibition of associated signaling pathways in various cancer cells and in in vivo models (Table 2). 
Table 2. In vivo assays performed in the studies reported in the review.

\begin{tabular}{|c|c|c|c|c|c|c|}
\hline Entry & NPs & Compound/Drugs Carried & Animal Models & Diseases Model & Biological Effects & Refs \\
\hline 1 & Gold & none & $\begin{array}{l}\text { orthotopic ovarian tumor models (A2780 } \\
\text { cells or SKOV3-ip) }\end{array}$ & Ovarian cancer & $\begin{array}{l}\text { Inhibition of tumor growth; } \\
\text { Inhibition of metastasis; } \\
\text { Inhibition of EMT }\end{array}$ & [48] \\
\hline 2 & Gold & none & $\begin{array}{l}\text { Female athymic nude mice orthotopic } \\
\text { ovarian tumor models (SKOV3-ip) }\end{array}$ & Ovarian cancer & $\begin{array}{l}\text { Drug sensitivity to cisplatin; } \\
\text { Reduction of tumor growth; } \\
\text { Inhibition of EMT }\end{array}$ & [49] \\
\hline 3 & Gold & none & Female C57BL6 mice & Melanoma & $\begin{array}{c}\text { Improvement of vascular morphology; } \\
\text { Increase vascular perfusion and decrease } \\
\text { permeability; } \\
\text { Alleviation of hypoxia; } \\
\text { Reduction of lung metastasis; } \\
\text { Inhibition of EMT }\end{array}$ & [51] \\
\hline 4 & Gold Nanoparticles & Cold plasma & $\begin{array}{l}\text { Athymic balb/c female nude mice } \\
\text { U87MG xenograft model }\end{array}$ & $\begin{array}{l}\text { Glioblastoma } \\
\text { Lung cancer }\end{array}$ & Reduction tumor growth & [53] \\
\hline 5 & Titanium dioxide & none & $\begin{array}{l}\text { Wild-type } \\
\text { zebrafish AB strain; } \\
\text { Male C57BL/6 mice }\end{array}$ & $\begin{array}{l}\text { Caudal regeneration; } \\
\text { Colitis }\end{array}$ & $\begin{array}{c}\text { Impairment of Caudal Fin Regeneration; } \\
\text { Colon injury }\end{array}$ & [54] \\
\hline 6 & D, L-lactic-co-glycolic acid (PLGA) & $\alpha$-Mangostin & 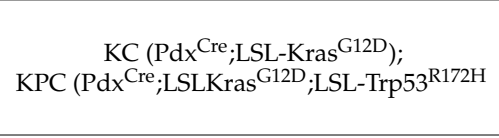 & Pancreatic cancer & $\begin{array}{c}\text { Inhibition of cancer growth; } \\
\text { development; } \\
\text { metastasis; } \\
\text { Inhibition of EMT }\end{array}$ & [57] \\
\hline 7 & D, L-lactic-co-glycolic acid (PLGA) & Wedelolactone & Female Swiss Albino mice & $\begin{array}{l}\text { Triple negative breast } \\
\text { cancer }\end{array}$ & $\begin{array}{l}\text { Reduction tumor volume; } \\
\text { Reduction cancer stem cells }\end{array}$ & [59] \\
\hline 8 & D, L-lactic-co-glycolic acid (PLGA) & Salinomycin & $\begin{array}{l}\text { Female athymic nude mice } \\
\text { AsPC-1-luc orthotopic model }\end{array}$ & Pancreatic cancer & $\begin{array}{l}\text { Reduction tumor growth; } \\
\text { Inhibition of EMT }\end{array}$ & [60] \\
\hline 9 & $\begin{array}{l}\text { Curcumin loaded selenium } \\
\text { nanoparticles (Se-Cu NPs) }\end{array}$ & Curcumin & $\begin{array}{l}\text { Ehrlich's ascites carcinoma } \\
\text { (EAC)-bearing mice. }\end{array}$ & Colon cancer & $\begin{array}{l}\text { Reduction tumor mass; } \\
\text { Increasing mean survival time }\end{array}$ & [63] \\
\hline 10 & $\begin{array}{c}\text { Curcumin loaded selenium } \\
\text { nanoparticles (Se-Cu NPs); } \\
\text { CD44-targeted DOX loaded } \\
\text { nanoparticles (PSHA-DOXNPs) }\end{array}$ & $\begin{array}{l}\text { Curcumin, } \\
\text { Doxorubicin }\end{array}$ & $\begin{array}{l}\text { Ehrlich's ascites carcinoma } \\
\text { (EAC)-bearing mice. }\end{array}$ & Colon cancer & $\begin{array}{l}\text { Decreased tumor burden; } \\
\text { Increased survival }\end{array}$ & [64] \\
\hline 11 & Gold Nanoparticles & Quercetin & Female Sprague-Dawley rats & Breast cancer & $\begin{array}{l}\text { Inhibition of tumor growth; } \\
\text { Inhibition of metastasis }\end{array}$ & [65] \\
\hline 12 & Mesoporous silica; PEG-PLA micelles & $\begin{array}{l}\text { Epigallocatechin } \\
\text { gallate/iron }\end{array}$ & $\begin{array}{l}\text { Female balb/c } \\
\text { mice }\end{array}$ & Breast cancer & $\begin{array}{l}\text { Suppression of metastasis; } \\
\text { Inhibition of EMT }\end{array}$ & [67] \\
\hline
\end{tabular}


Table 2. Cont

\begin{tabular}{|c|c|c|c|c|c|c|}
\hline Entry & NPs & Compound/Drugs Carried & Animal Models & Diseases Model & Biological Effects & Refs \\
\hline 13 & Layered double hydroxide & Etoposide & Female BALB/c nude mice & Glioblastoma & $\begin{array}{l}\text { Reduction of tumor growth; } \\
\text { Induction of apoptosis; } \\
\text { Inhibition of pluripotency; } \\
\text { Inhibition of EMT } \\
\end{array}$ & [68] \\
\hline 14 & ADH-1 peptide-modified liposomes & Paclitaxel & Female BALB/c nude mice & Breast cancer & $\begin{array}{l}\text { Inhibition of tumor growth; } \\
\text { Enhancement of chemosensitivity }\end{array}$ & [69] \\
\hline 15 & Gold nanoparticles & $\begin{array}{c}\text { Dexamethasone (DSH) } \\
\text { thiol derivative } \\
\text { Withaferin (WFA) }\end{array}$ & Old female C57BL/6J mice & Melanoma & $\begin{array}{l}\text { Induction of apoptosis; } \\
\text { Inhibition of tumor growth; } \\
\text { Reduction in mice mortality; } \\
\text { Inhibition of EMT }\end{array}$ & [72] \\
\hline 16 & Albumin based nanoparticles & Arsenic trioxide & Xenograft model & $\begin{array}{l}\text { Nasopharyngeal } \\
\text { carcinoma }\end{array}$ & $\begin{array}{l}\text { Reduction tumor growth; } \\
\text { Inhibition of EMT }\end{array}$ & [74] \\
\hline 17 & Liposome & ${ }^{188} \operatorname{Re}$ & $\begin{array}{l}\text { Balb/C nude mice Orthotopic xenograft } \\
\text { model }\end{array}$ & Ovarian cancer & $\begin{array}{l}\text { Reactivation p53; } \\
\text { Switch to oxidative phosphorylation; } \\
\text { Inhibition of EMT }\end{array}$ & [75] \\
\hline 18 & Liposome & ${ }^{188} \operatorname{Re}$ & $\begin{array}{l}\text { Balb/C nude mice Orthotopic xenograft } \\
\text { model }\end{array}$ & $\begin{array}{l}\text { Head and neck } \\
\text { squamous cell } \\
\text { carcinoma }\end{array}$ & Suppression of tumor growth & [76] \\
\hline 19 & Liposome & ${ }^{188} \operatorname{Re}$ & $\begin{array}{l}\text { Balb/C nude mice Orthotopic xenograft } \\
\text { model }\end{array}$ & $\begin{array}{l}\text { Head and neck } \\
\text { squamous cell } \\
\text { carcinoma }\end{array}$ & $\begin{array}{l}\text { Suppression of tumor growth; } \\
\text { Survival; } \\
\text { Inhibition of EMT; } \\
\text { Inhibition of proliferation markers; } \\
\text { Accumulation in tumor site }\end{array}$ & [77] \\
\hline 20 & Liposome & Simvastatin, Paxicitel & A549T xenograft mouse model & Lung cancer & $\begin{array}{l}\text { Reversion of chemoresistance to PTX in vivo; } \\
\text { Arrest of cell growth; } \\
\text { Inhibition of EMT; } \\
\text { Change of cell polarization of TAM in vivo }\end{array}$ & [78] \\
\hline 21 & Polypeptide micelles (PEG-PLL-PLLeu) & $\begin{array}{l}\text { ZEB1 siRNA } \\
\text { DOX }\end{array}$ & $\begin{array}{l}\text { Female BALB/c nude mice } \\
\text { H460 xenograft model }\end{array}$ & $\begin{array}{l}\text { Non-small cell lung } \\
\text { cancer (NSCLC) }\end{array}$ & $\begin{array}{l}\text { Inhibition of EMT; } \\
\text { Repression of CSC properties; } \\
\text { Inhibition of metastasis; } \\
\text { Inhibition of tumor growth } \\
\end{array}$ & [82] \\
\hline 22 & $\begin{array}{l}\text { Polyamidoamine dendrimers (PAMAM) } \\
\text { and Hyaluronic-acid conjugated } \\
\text { mesoporous silica nanoparticles } \\
\text { (MSN-Has) }\end{array}$ & $\begin{array}{l}\text { TWIST1 siRNA } \\
\text { Cisplatin }\end{array}$ & 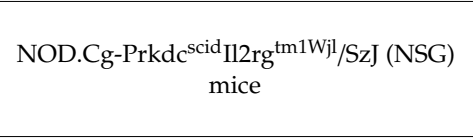 & Ovarian cancer & $\begin{array}{l}\text { Inhibition of tumor growth; } \\
\text { Sensitivity to cisplatin; } \\
\text { Inhibition of EMT }\end{array}$ & {$[83,84]$} \\
\hline 23 & Mesoporous Silica & TWIST1 siRNA & 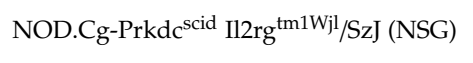 & Melanoma & $\begin{array}{l}\text { Reduction of tumor burder; } \\
\text { Inhibition of EMT }\end{array}$ & [85] \\
\hline
\end{tabular}


Table 2. Cont

\begin{tabular}{|c|c|c|c|c|c|c|}
\hline Entry & NPs & Compound/Drugs Carried & Animal Models & Diseases Model & Biological Effects & Refs \\
\hline 24 & $\begin{array}{l}\text { PEI-PDHA } \\
\text { PEG-PDHA } \\
\text { P85-PEI/TPGS }\end{array}$ & $\begin{array}{l}\text { TWIST1 siRNA } \\
\text { Snail siRNA } \\
\text { Paclitaxel }\end{array}$ & $4 \mathrm{~T} 1$ tumor-bearing mice models & Breast cancer & $\begin{array}{l}\text { Reduction of metastasis; } \\
\text { Inhibition of cell invasion; } \\
\text { Inhibition of ECM degradation } \\
\text { Inhibition of tumor growth }\end{array}$ & {$[111,112]$} \\
\hline 25 & Polyamidoamine dendrimers (PAMAM) & TWIST1 siRNA & $\begin{array}{l}\text { NOD.Cg-PrkdcscidIl2rgtm1Wjl/SzJ (NSG) } \\
\text { mice }\end{array}$ & Breast cancer & Biodistribution in tumor site & [87] \\
\hline 26 & (PLGA)2-PEI-DMMA nanoparticles & NgBR siRNA & $\begin{array}{l}\text { Female BALB/c nude mice } \\
\text { Orthotopic model }\end{array}$ & Breast cancer & Reduction of metastasis & [88] \\
\hline 27 & ECO lipid carrier & $\beta 3$ integrin & $\begin{array}{c}\text { Female nude mice (nu/nu Balb/c } \\
\text { background) }\end{array}$ & $\begin{array}{l}\text { Triple negative breast } \\
\text { cancer }\end{array}$ & $\begin{array}{l}\text { Reduction of primary tumor burden; } \\
\text { Inhibition of metastasis; } \\
\text { Inhibition of EMT }\end{array}$ & [89] \\
\hline 28 & ECO lipid carrier & DANCR siRNA & $\begin{array}{l}\text { Nude athymic mice } \\
\text { MDA-MB-231 and } \\
\text { BT549 xenograft model }\end{array}$ & $\begin{array}{l}\text { Triple negative breast } \\
\text { cancer }\end{array}$ & $\begin{array}{l}\text { Reduction of tumor growth; } \\
\text { Inhibition of EMT }\end{array}$ & [90] \\
\hline 29 & $\begin{array}{l}\text { Poly(lactide-co-glycolide) acid } \\
\text { nanoparticles (PLGA NPs) }\end{array}$ & DCAMKL-1 siRNA & $\begin{array}{l}\text { Male athymic nude mice }(\mathrm{NCr}-\mathrm{nu} / \mathrm{nu}) \\
\text { HCT116 cells orthotopic models }\end{array}$ & Colon cancer & $\begin{array}{l}\text { Arrest in tumor growth; } \\
\text { Inhibition of EMT; } \\
\text { Regulation of oncogenic miRNAs network }\end{array}$ & [91] \\
\hline 30 & $\begin{array}{c}\text { Polyethylene } \\
\text { glycol-polyethylenimine-magnetic iron } \\
\text { oxide (PEG-PEI-IONPs) }\end{array}$ & $\begin{array}{l}\text { microRNA-21 antisense } \\
\text { oligonucleotides; } \\
\text { Gemcitabine }\end{array}$ & Female BALB/c nude mice & Pancreatic cancer & $\begin{array}{l}\text { Reduction tumor growth; } \\
\text { Inhibition of metastasis }\end{array}$ & [95] \\
\hline 31 & $\begin{array}{c}\text { Gelatinases-stimuli poly(ethylene } \\
\text { glycol)-peptide-poly(e-caprolactone) } \\
\text { copolymer }\end{array}$ & $\begin{array}{l}\text { miR-200c } \\
\text { Docetaxel }\end{array}$ & BGC-823 gastric tumor-bearing mice & $\begin{array}{c}\text { Gastric } \\
\text { adenocarcinoma }\end{array}$ & $\begin{array}{l}\text { Suppression tumor growth; } \\
\text { Drug sensitivity; } \\
\text { Inhibition of EMT }\end{array}$ & [97] \\
\hline
\end{tabular}




\subsubsection{Natural Products}

The development of drugs and therapeutic molecules derived by natural products represents an exciting opportunity for the treatment and prevention of cancer. Interestingly, in recent years, several studies reported the use of nanomaterials as carriers of natural substances, alone or in combination with chemotherapy, to treat cancer by suppressing EMT and the associated TFs and signaling pathways [57-67]. The main natural products employed are commented on below.

\subsection{2. $\alpha$-Mangostin and Anthothecol}

Among the plethora of plant-derived compounds having therapeutic proprieties, $\alpha$-mangostin and anthothecol have elicited particular interest for antioxidant, antimicrobial, anticancer, and anti-inflammatory properties [113-117]. The $\alpha$-mangostin was found to suppress EMT by inhibiting MMP2 and MMP9 and increasing E-cadherin expression by downregulating the PI3K/Akt pathway [118].

However, the in vivo application of most polyphenols was limited due to poor bioavailability, poor solubility, and low pharmacokinetic profiles [119].

To overcome these obstacles and increase the efficacy, $\alpha$-mangostin and anthothecol have been encapsulated into the core of poly (D, L-lactic-co-glycolic acid) (PLGA) nanoparticles (Mang-NPs and Antho-NPs) and evaluated as a therapeutic approach in pancreatic cancer stem cells $[57,58]$.

PLGA is largely used for drug delivery because it presents excellent biodegradable and biocompatible properties [120]. Mang-NPs and Antho-NPs were found to inhibit EMT by upregulating E-cadherin and inhibiting N-cadherin and transcription factors Slug, Snail, and Zeb1, as well as by downregulating pluripotency maintaining factors Nanog, c-Myc, and Oct4 and components of Shh pathway $[57,58]$. EMT suppression by these nanomaterials resulted in the inhibition of proliferation, migration, and development of pancreatic cancer cells as well as the reduction of malignant transformation and metastasis in in vivo models $[57,58]$.

\subsubsection{Wedelolactone}

Wedelolactone $(\mathrm{Wdl})$ is another plant-derived polyphenolic compound that has been found to inhibit androgen-independent prostate cancer [121], endometrial and ovarian cancer cell growth, [122] and suppress the EMT of alveolar epithelial cells [123]. In order to increase its effectiveness and diminish toxic side effects, $\mathrm{Wdl}$ has been encapsulated into PLGA nanoparticles (nWdl) and used as anticancer therapy in breast cancer [59]. These polymeric nanocomplexes prevented EMT, reduced cell migration and invasion, and diminished the percentage of breast cancer stem cells (brCSCs) in MDA-MB-231 cells [59]. Intriguingly, $\mathrm{nWdl}$ also sensitized brCSCs to paclitaxel, reducing the percentage of ALDH+ brCSCs, and suppressed tumor growth in mice [59].

\subsubsection{Salinomycin}

Salinomycin (SAL) is a monocarboxylic polyether antibiotic isolated from Streptomyces albus strain with activity against pancreatic cancer stem cells [124,125].

Interestingly, SAL also was found to reduce EMT-mediated multidrug resistance in gastric cancer [126]. However, the use of NPs offer several advantages for SAL delivery, including improved solubilization, increased intratumor accumulation through EPR effect, high stability, and low side effects [127].

In a recent study, SAL was delivered in an orthotopic model of pancreatic cancer using PLGA nanoparticles [60]. SAL-loaded PLGA NPs led to EMT inhibition and apoptosis induction in AsPC-1 pancreatic cancer cells as well as reduction of tumor growth in AsPC-1-luc orthotopic pancreatic model [60]. 
In another study, SAL was delivered using polymeric micelles and was shown to repress EMT in lung cancer, leading a reduction of migration capability of A459 lung cancer cells without interfering with cell proliferation [61].

\subsubsection{Gallic Acid}

Gallic acid (GA) is a potent antioxidant discovered in plants and many fruits and is beneficial in inhibiting metastasis in glioma [128], gastric [129], and prostate cancer cells [130]. Some reports showed that GA shows efficacy against EMT-related markers, and it is a potential therapeutic agent in pulmonary fibrosis in mice [131].

Different studies highlighted that silver nanoparticles (Ag-NPs) possess a high therapeutic potential against a plethora of cancer cells by modulating autophagy and acting as cytotoxic agents by itself [132]. In addition, it has been reported that these nanomaterials can act as nanocarriers to deliver therapeutic molecules, such as GA, hampering EMT, and thus reducing the metastatic potential of A459 lung cancer cells [62].

\subsubsection{Curcumin}

Curcumin, a phytochemical derived from Curcuma longa, has been largely exploited in combination with traditional chemotherapeutics to increase their anticancer efficacy [133]. Besides, recent reports showed that curcumin suppresses EMT and metastasis in various tumor cells [134-136].

However, the therapeutic efficacy of curcumin is limited by its poor bioavailability and absorption, rapid metabolism, and rapid systemic elimination [137]. Therefore, the use of certain nanoparticles represents an effective way to improve the bioavailability and pharmacokinetics, thus enhancing its therapeutic effect, internalization, and tumor targeting [137].

Several studies reported the potential anticancer efficacy of selenium nanoparticles (Se-NPs) on prostate, liver, cervical, and breast cancer cells [138-140].

In this regard, curcumin-loaded selenium nanoparticles (Se-Cu-NPs), alone and/or in combination with doxorubicin (DOX), were found to inhibit EMT and reduce inflammation, metastasis, and chemoresistance in colon cancer. This occurred consequently to the alterations of crucial EMT-TFs, such as Snail and NF-kB $[63,64]$. Notably, Se-Cu-NPs reduced the tumor mass, enhancing the mean survival time of tumor-bearing Ehrlich's ascites carcinoma (EAC) mice [63,64].

\subsubsection{Quercetin}

Quercetin $(\mathrm{Qu})$ is a bioflavonoid that possesses anticancer properties since it was found to modulate EMT, proliferation, survival, and differentiation of tumor cells [141-143]. However, the therapeutic efficacy of $\mathrm{Qu}$ is limited by its poor solubility in water. In order to enhance Qu effectivity, a gold nanoparticle-based drug delivery system for Qu (AuNPs-Qu-5) has been formulated and employed against breast cancer cells. These nano-conjugates were found to suppress EMT, leading to the reduction in angiogenesis, tumor growth, and metastasis in MCF-7 and MDA-MB-231 breast cancer cell lines. Notably, treatment with these nanoparticles led to tumor regression in 7,12-dimethylbenz(a)anthracene (DMBA)-induced mammary carcinoma in Sprague-Dawley rats [65].

Other approaches have exploited the use of liposomes, which present many advantages as nanocarriers, presenting excellent biocompatibility and improving the solubility, stability, and pharmacokinetic properties of the drugs [144]. In this regard, it has been reported that esophageal cancer stem cells exposed to nanoliposomal quercetin (nLQ) showed inhibited EMT and the modulation of a variety of EMT-related proteins, such as HDAC1 and E-cadherin [66]. The reversion of the mesenchymal towards the epithelial phenotype reflects the capacity of these nanoparticles to act as a cancer therapeutic agent. 


\subsubsection{Epigallocatechin Gallate}

Epigallocatechin gallate (EGCG), a compound extracted from green tea, has been proven to have multiple anticancer, anti-inflammatory, anti-EMT, and anti-oxidant proprieties [145-147]. Despite its ability to act as an excellent anticancer drug, EGCG displays some limitations related to stability, bioavailability, and metabolic conversion under physiological conditions $[148,149]$.

In order to address these issues, an innovative coating membrane where EGCG is coordinated with ferric ions to generate epigallocatechin gallate/iron nanocomplexes (EIN) [67] has been reported. EIN were used to coat mesoporous silica nanoparticles (MSN) and PEG-PLA micelles (Mic) to form MSN@EIN and Mic@EIN, respectively. MSN@EIN and Mic@EIN displayed ideal biocompatibility, low cytotoxicity, and increased intracellular drug concentration leading to EMT inhibition when delivered in breast cancer cells. These nanostructures were able to eliminate EMT-type cancer cells in in vivo models, to decrease cancer cell migration, and to prevent drug resistance [67]. Moreover, it has also been described that MSNs coated with epigallocatechin gallate reduced EMT and tumor metastasis when delivered in in vivo models of breast cancer [67].

\subsection{Synthetic Drugs}

Different nanomaterials have been exploited to deliver synthetic chemotherapeutics and chemicals inside cancer cells reverting EMT and chemoresistance, and prevent metastasis in a plethora of tumor types [68-78].

\subsubsection{Etoposide}

Etoposide (VP16) is a semisynthetic phytophthora toxin widely used as a chemotherapeutic agent for the treatment of several cancers [150,151]. However, many studies showed that VP16 fails against glioma stem cells (GSCs), resulting in enhanced tumor metastasis and recurrence $[152,153]$.

Many factors were correlated with VP16 resistance to CSCs, including poor water solubility, metabolic inactivation, low bioavailability, enhanced drug extrusion by ATP-binding cassette multidrug transporters, and increased rates of DNA repair [154-156].

In order to bypass these obstacles and improve the clinical applications, layered double hydroxide (LDH) nanocomposites (L-V) have been complexed with Etoposide (VP16). Wang and colleagues showed that these nanocomplexes were able to inhibit EMT modulating EMT-related signaling pathways, leading to the elimination of glioma stem cells and reduction of tumor growth [68]. In in vivo GSCs, xenograft mice model L-V could overcome drug resistance, leading to a reduction in tumor growth [68].

\subsubsection{ADH-1}

ADH-1 (N-AC-CHAVC-NH ${ }_{2}$ ), a cyclic pentapeptide obtained from the His-Ala-Val (HAV) site of $\mathrm{N}$-cadherin, is a potent antagonist of $\mathrm{N}$-cadherin-mediated adhesion and invasion. In this regard, it was reported that ADH-1 was able to inhibit $\mathrm{N}$-cadherin dependent tumor progression in vitro and in vivo [157-159]. As mentioned above, liposomes are excellent, easily modifiable nanocarriers for anticancer drugs, which enhance their therapeutic efficiency and represent promising cancer treatments in the future.

In a recent study, ADH-1 peptide-modified liposomes (A-LP) were prepared to facilitate the delivery of the chemotherapeutic drug paclitaxel (PTX) to tumor cells undergoing EMT [69].

Intriguingly, these liposomal nanocomplexes were able to inhibit the EMT process and breast cancer cell migration and restore chemosensitivity, exhibiting strong antitumor efficacy in vivo [69].

For the treatment of cancer through EMT suppression, the use of several systems based on mesoporous silica (MSNs) and mesoporous titanium (NTNs) nanoparticles functionalized with hyaluronic acid (HA), DOX, and ADH-1 [70,71] has been reported. These multifunctional nanocarriers, alone and/or in combination with photodynamic therapy (PDT), led to EMT suppression in A549 lung 
carcinoma cells, thus promoting drug sensitivity and inhibition of cell migration, and reduced the metastatic potential $[70,71]$.

\subsubsection{Dexamethasone}

Glucocorticoids (GCs) are a family of steroid hormones acting through the glucocorticoid receptor (GR), a member of the nuclear receptor superfamily [160]. Recent studies report that GCs can block EMT of mink lung epithelial cells and estrogen receptor (ER)-negative breast cancer cells [161,162]. Synthetic GCs are largely used as anti-inflammatory drugs [163] and dexamethasone (Dex) was found to reduce EMT in colon cancer cells as well as in human peritoneal mesothelial cells [164,165]. However, long-term systemic exposure to Dex causes a variety of adverse effects [166], and novel strategies are needed to deliver Dex in cancer cells.

In this regard, a study by Agarwalla et al. reports that AuNPs modified with dexamethasone (DEXA) and withaferin-A were able to inhibit EMT in tumor cells preventing metastasis [72]. These nanostructures led to glucocorticoid receptor-dependent selective cytotoxicity, inhibited melanoma growth in mice, and suppressed mice mortality [72].

\subsubsection{Arsenic Trioxide}

Arsenic trioxide (ATO) exhibits anticancer effects by degrading the oncogenic EVI1 protein, an interactor of Snail and HDAC1 active in E-cadherin repression and EMT induction [167].

Additionally, several studies showed that ATO could suppress EMT in gastric and liver cancer by different mechanisms $[168,169]$. Despite some successes as anti-EMT agent, ATO has poor bioavailability and causes adverse reactions that limit its clinical application in treating human cancers [170]. Hence, novel approaches to reduce off-target effects and improve bioavailability are required.

In this sense, zinc arsenite (ZnAs) NPs have been exploited as a molecular scaffold to deliver ATO in nasopharyngeal carcinoma (NCO) cells and hepatocarcinoma (HCC) tumor models [73,74]. ATO-loaded zinc arsenite (ZnAs) nanocomplexes inhibited EMT process via SHP-1/JAK2/STAT3 pathway and by reducing the expression of EMT-related proteins, leading to reduced tumor growth in vivo $[73,74]$.

\subsubsection{Rhenium- 188}

Rhenium-188 ( $\left.{ }^{188} \mathrm{Re}\right)$ is a high-energy $\beta$-particle radionuclide obtained from an alumina-based tungsten-188 $\left({ }^{188} \mathrm{~W}\right) /{ }^{188}$ Re generator [171]. The short average penetration distance of $\beta$-particles in soft tissues makes ${ }^{188}$ Re an ideal radionuclide for tumor ablation with reduced activity on the surrounding normal tissues [172].

Interestingly, the radiopharmaceuticals generated through the conjugation of liposomes with radionuclide ${ }^{188}$ Re are considered useful for theranostics purposes in cancer diseases by enhancing internal circulation without acute toxicity through the EPR effect [173].

Polyethylene glycol (PEG)-coated ${ }^{188}$ Rhenium-liposome has been shown to inhibit EMT in murine models of ovarian tumors [75] and human head and neck squamous cell carcinoma (HNSCC) [76,77], exhibiting killing efficacy and tumor growth delay through induction of let7 miRNA and glycolysis inhibition.

The therapeutics delivered by nanostructures commented on here are represented in Figure 4. 

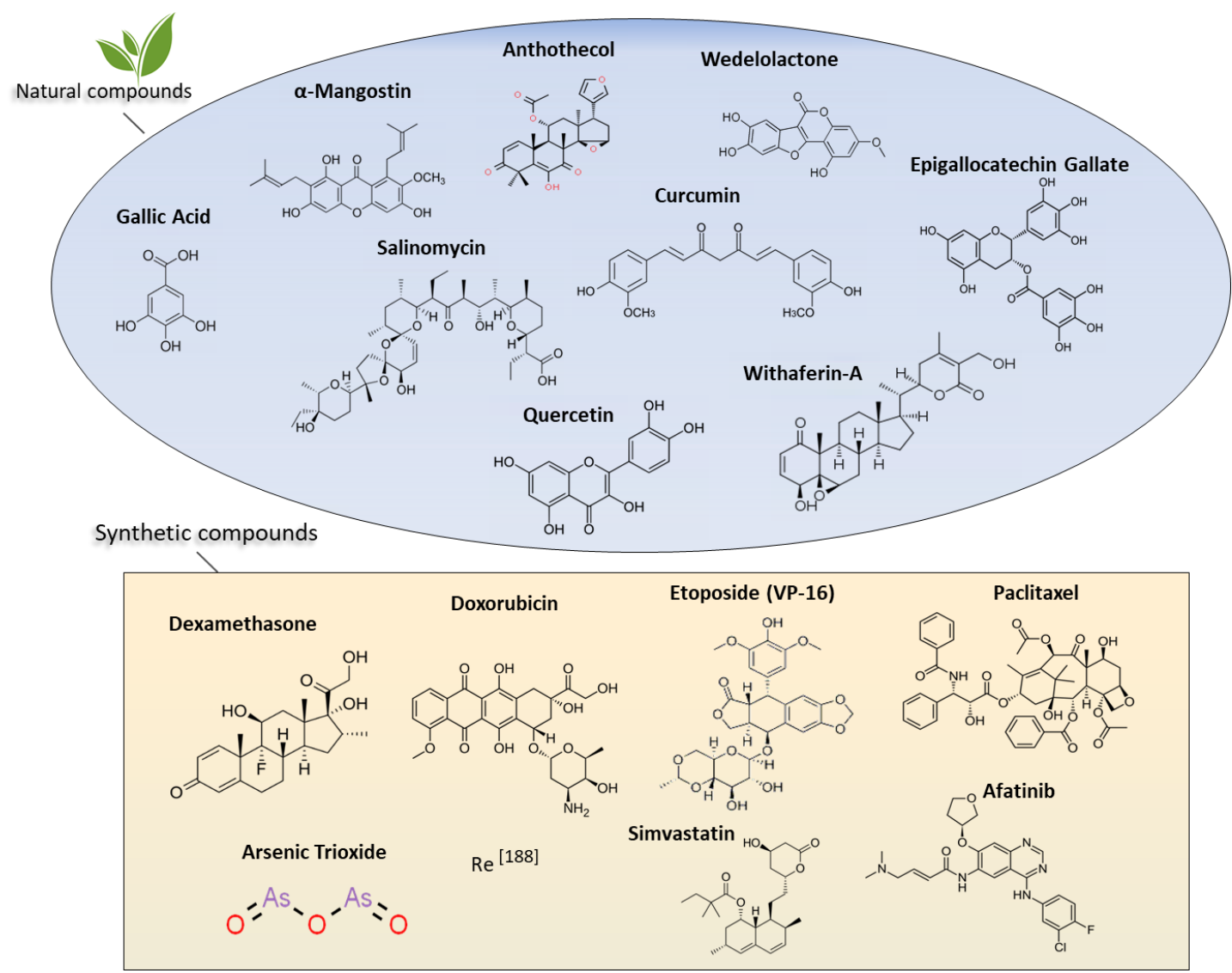

Figure 4. Chemical structures of natural substances and synthetic therapeutics delivered by nanomaterials active in tumor EMT inhibition discussed along this review.

\subsection{Nanoparticles for Nucleic Acids Delivery to Revert EMT Phenotype}

Therapeutic nucleic acids have been largely explored as anticancer tools [174], particularly RNA-based derivatives, such as small interfering RNAs (siRNAs), and micro RNA (miRNA) mimics and antagomirs (see below). Although their use in targeting EMT is promising, nucleic acids have to face important obstacles limiting their therapeutic effect, including nucleic acid stability and successful delivery in vivo. In this regard, a variety of nanocarriers have been developed to address these issues, opening novel therapeutic opportunities.

\subsubsection{Delivery of SiRNAs Against EMT TFs and Other EMT-Related Genes}

Small interfering RNAs (siRNAs) are small (around 20 nucleotides), noncoding RNAs endowed with the ability to downregulate gene expression through a process known as RNA interference (RNAi) [175]. This technology involves a post-transcriptional mechanism that inhibits gene expression by promoting the cleavage on a specific region of the target messenger RNA (mRNA) and shows promising therapeutic results in cancer treatment.

However, the clinical use of siRNA is still limited by its rapid degradation, nonspecific distribution, and poor cellular uptake [176]. Therefore, delivery systems able to preserve the integrity and improve the delivery of siRNAs to the site of action in the cytosol are required to develop successfully siRNA-based therapeutics.

Recently, some nanomaterials have been exploited to deliver therapeutic siRNAs against key EMT-related genes in cancer cells, which are commented on below and resumed in Figure 5. 


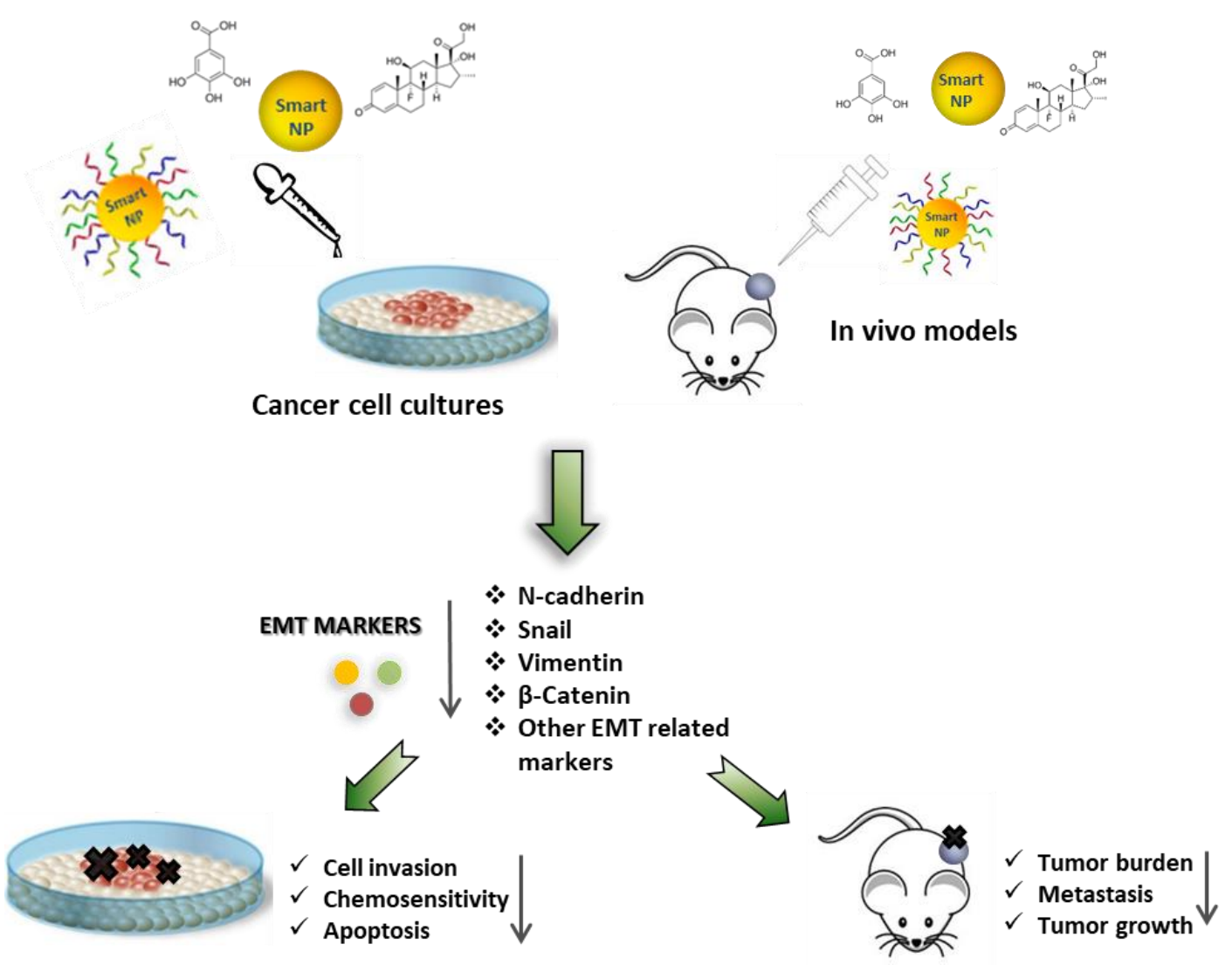

Figure 5. Nanoparticles as a tool for the delivery of natural substances, synthetic therapeutics, and nucleic acids to revert the EMT phenotype. Schematic representation showing the effects of nanoparticles functionalized with natural substances, synthetic therapeutics, and nucleic acids, in targeting the EMT program. The resulting EMT reversion (MET) is able to limit tumor cell migration and invasion and to enhance chemosensitivity, as well as to reduce tumor growth.

\subsubsection{SNAIL-1}

SNAIL-1 is the most characterized EMT TF, originally discovered as an E-cadherin repressor [177]. The involvement of SNAIL-1 in the regulation of EMT and metastasis and its roles in both drug and immune resistance [29] make it an attractive target for novel anticancer drugs.

Chitosan is a biocompatible and biodegradable polymer used in nanomedicine for siRNA delivery [178]. Some studies have exploited carboxymethyl dextran (CMD) chitosan nanoparticles (ChNPs) for the double encapsulation of Snail siRNA and anticancer drugs such as doxorubicin (DOX) and SN38, for synergistic cancer therapy [79-81]. These nanocomplexes led to EMT inhibition and significant changes in the expression of EMT-related genes. The reversion of the mesenchymal phenotype was accompanied to apoptotic cell death, inhibition of cell growth and metastasis, and enhancement in drug sensitivity in colorectal, lung, and prostate cancer and in vivo [79-81].

\subsubsection{ZEB1}

The EMT TF ZEB1 promotes carcinogenesis and metastasis by inducing an invasive phenotype and by conferring stem-like properties [27]. Therefore, targeting this TF may reduce cancer malignancy and improve the oncologic outcome for cancer patients.

Multifunctional polypeptide micelle nanoparticles (NPs) have been employed as nanocarriers for the delivery of ZEB1-specific siRNA in combination with DOX therapy in lung cancer [82]. The combined treatment synergistically reduced EMT, repressed CSC proprieties in vitro and in vivo, and finally suppressed metastasis [82]. Therefore, targeting ZEB1 with nanostructures represents a promising strategy to inhibit EMT and cancer metastasis. 


\subsubsection{TWIST1}

Differently than SNAIL-1 and ZEB1, TWIST1 is a more potent mesenchymal inducer than epithelial repressor [179]. TWIST1 plays a critical role in some physiological processes leading to cancer metastasis [180] and has recently gained significant interest in cancer therapy.

A plethora of studies reported that siRNAs against TWIST1 delivered by nanoparticles inhibited the EMT process in several tumors, leading to the reduction of tumor progression and metastasis and sensitizing cancer cells to chemotherapy drugs and radiotherapy [83-87,111,112,181,182].

In this regard, Finlay and colleagues reported that the delivery of TWIST1-targeting siRNAs with a polyethyleneimine-coated mesoporous silica nanoparticle (MSN) was able to revert the mesenchymal phenotype of MDA-MB-435S melanoma cells, thus leading to the inhibition of migratory potential and tumor burden in vivo [85].

In another study, a TWIST1-specific siRNA was delivered in ovarian and breast cancer cells by polyamidoamine dendrimers (PAMAM) and hyaluronic acid conjugated mesoporous silica nanoparticles (MSN-HAs). These nanoformulations inhibited the EMT program, reversing chemoresistance to cisplatin and leading a reduction of tumor growth in mice models $[83,84,87]$.

$\mathrm{Li}$ and coworkers reported that $\mathrm{pH}$-sensitive polymeric nanomaterials loaded with siRNAs targeting TWIST1 in combination with paclitaxel suppressed EMT, reducing tumor growth and metastasis as well as ECM degradation in breast cancer cells and orthotopic mice models [111,112].

\subsubsection{Nogo-B Receptor}

Nogo-B receptor (NgBR) plays a fundamental role in regulating EMT and promoting chemoresistance and metastasis in breast and lung cancer cells [183-185].

In a recent study, a polymeric nanostructure responsive to the tumor extracellular acidity has been developed for the delivery of siRNAs against NgBR in tumor tissues [88]. The nanoparticles presented a negative surface charge in blood circulation and healthy tissues, but the charge changed to positive through the hydrolysis of a sensitive molecule exposed on the surface of the micelles. This change promoted the cellular uptake of siRNAs, leading the inhibition of $\mathrm{NgBR}$ in tumor-bearing tissues.

Thus, the system efficiently inhibited the EMT process resulting in attenuated cell migration and distant metastasis in breast cancer [88].

\subsection{6. $\beta 3$ Integrin}

Among integrin isoforms, adhesion receptors implicated in cell-to-cell and cell-ECM interactions, $\beta 3$ integrin has been mainly studied in tumors due to its effect on angiogenesis [186]. To this respect, several nanomaterials have been used to target $\beta 3$ integrin in vivo resulting in the blockage of mesenchymal phenotype and cancer metastasis [89,90]. For instance, the multifunctional cationic lipid-based carrier (1-aminoethyl)iminobis[N-oleicylsteinyl-1-aminoethyl)propionamide] (ECO) was used to deliver siRNAs targeting $\beta 3$ integrin in triple-negative breast cancer (TNBC) cells. The treatment with ECO/siRNAs nanostructures resulted in the inhibition of cellular migration, tumor spheroid formation, and 3-dimensional organoid growth [89,90]. Moreover, ECO lipid nanocomplexes led to a reduction of tumor growth and metastasis in vivo [89,90], thus representing a promising therapeutic approach to modulate signaling pathways EMT-related involved in TNBC.

\subsubsection{DCAMKL-1}

The novel putative intestinal and pancreatic stem cell marker DCAMKL-1 [187,188], a microtubule-associated kinase, plays a key role in tumorigenesis by downregulating tumor suppressor microRNAs thus inducing tumor promoters specific targets such as ZEB1, ZEB2, and Notch-1 [189,190].

Polymeric nanostructures have been employed to deliver DCAMKL-1 siRNA to modulate potential essential genes cancer regulators [91]. It has been reported that the administration of these nanocomplexes into HCT116 xenograft mice models resulted in the upregulation of EMT 
inhibitor miR-200a and downregulation of EMT-associated markers leading tumor growth arrest via let-7a and miR-144 dependent mechanisms [91]. Hence, nanoparticle-based delivery of siRNAs targeting DCAMKL-1 might offer a novel strategy for cancer treatment through the regulation of oncogenic signaling.

\subsubsection{Wnt-1}

Wnt-1 is an extracellular protein implicated in morphogenesis. In tumors, Wnt- 1 is frequently upregulated, and its activity is linked to the stabilization and activation of the oncogene $\beta$-catenin, which leads to EMT activation [17]. Hence, dysregulation in Wnt-1/ $\beta$-catenin pathway plays a critical role in carcinogenesis and chemoresistance and represents a valid target for novel cancer therapy [191]. Furthermore, Wnt-1 can be targeted to increase the efficacy of complementary therapies. In this regard, polyethylene glycol-polyethyleneimine-chlorin e6 (PEG-PEI-Ce6) nanoparticles were used to deliver siRNAs against Wnt-1 in an oral squamous cell carcinoma that was treated with photodynamic therapy (PDT). In this case, it was observed that PDT alone led to an activation of the EMT process, inhibiting the antitumoral effect. However, the combination strategy mentioned above produced a significant reduction of some proteins crucial to the EMT process, enhancing the antitumoral activity of PDT [92].

\subsubsection{STAT3}

STAT3 is a transcription factor activated by cytokines elicited during inflammatory-immune responses such as interleukin (IL)-6 and -10. STAT3 plays a role in EMT by cooperating with TGF $\beta$ signaling [192]. Constitutive activation of STAT3 has been linked to cell growth, differentiation, survival, and metastasis $[193,194]$. Among the different drugs targeting STAT3, some nanomedicines have been exploited for this aim and represent a promising therapeutic approach.

In this sense, cationic solid lipid nanoparticles (SLN) were employed to deliver decoy oligodeoxynucleotides (ODN) to block STAT3 in ovarian cancer. SLN-STAT3 decoy ODN complexes led the reversion of EMT phenotype, reduced cell invasion, and increased apoptotic and autophagic cell death [93].

\subsubsection{AXL Kinase}

AXL is a member of the receptor tyrosine kinase (RTK) family and can enable several downstream pathways through interaction with Epidermal growth factor receptor (EGFR) [195].

Additionally, a recent study showed that the overexpression and activation of AXL induced the EMT program in cancer cells and was associated with increased metastasis and chemoresistance [196].

For these reasons, AXL kinase represents a valid therapeutic target to counteract cancer. In this sense, Suresh et al. developed antibody functionalized gelatin nanoparticles (GAb) for effective cytoplasmatic delivery of anti-AXL siRNA in lung cancer cells [94]. These nanostructures repressed EMT by downregulating MMPs production and key EMT-related proteins, such as N-cadherin and vimentin, sensitizing H820 and H1975 cell lines to tyrosine kinase inhibitors [94].

\subsection{Delivery of miRNAs Inhibiting EMT}

miRNAs are endogenous, small, noncoding RNAs that function in the regulation of gene expression, whose dysregulation is related to many pathological processes, including EMT and tumorigenesis [197]. Hence, re-establishing endogenous intracellular levels of miRNAs may reverse EMT and counteract cancer progression. However, the low stability and the difficulty in delivering miRNAs into cells limits its application [198]. For these reasons, nanocarriers are explored to deliver miRNA derivatives to block oncogenic miRNAs or to restore the physiological levels of tumor suppressor miRNAs. Selected miRNAs involved in the regulation of the EMT delivered by nanomaterials are commented below. 


\subsection{1. miRNA-21}

miRNA-21 has been shown to play a pivotal role in cancer initiation and progression in many tumors and represents a target for the treatment of pancreatic cancer [199]. In a recent study, a multifunctional nanoscaffold was developed using polyethylene glycol-polyethylenimine-magnetic iron oxide NPs (PEG-PEI-IONPs) for combined therapy of miRNA-21 antisense oligonucleotides (ASO-miR-21) and gemcitabine (Gem) [95]. This nanocomplex suppressed EMT, leading to the reduction of the migration and invasion capabilities of pancreatic cancer cells in vitro and the tumor growth and metastasis in vivo [95].

\subsection{2. miRNA-139}

miRNA-139 has been found to be downregulated in various types of cancer, including colorectal cancer $[200,201]$. Further data have shown that low miR-139 expression is related to the aggressiveness of colon cancer [201] and a high incidence of chemoresistance and metastasis via EMT activation [200]. Therefore, miR-139 might represent a therapeutic target by counteracting EMT signaling. In this sense, multifunctional lipid-polymer hybrid nanoparticles (LPNs) [202] composed of PLGA and PEG-lipids has been used to deliver miR-139 in colorectal cancer cells [96]. This nanostructure was modified with two cell-penetrating peptides (CPP) to enhance targeting and penetrating characteristics in colorectal cancer cells. The system was able to suppress EMT and cancer cell migration by downregulating $\beta$-catenin and Slug, enhancing the sensitivity to afatinib [202] concomitantly.

\subsection{3. miRNA-200c}

miRNA-200c, a member of the miRNA-200 family, can reverse the EMT by attenuating the invasive ability of epithelial cells and increasing E-cadherin expression [203-205]. Liu and coworkers developed gelatinases stimuli nanoparticles in order to co-deliver miRNA-200c and docetaxel (DOC). These nanomaterials inhibited EMT in both CSCs and non-CSCs gastric cancer cells [97] and significantly enhanced the cytotoxicity of DOC. Besides, this nanoformulation suppressed tumor growth in vivo, representing a promising strategy for co-delivery of nucleic acid and drugs, and at the same time, to suppress CSCs and non-CSC cancer cells.

\subsubsection{Delivery of miRNAs Mimics}

AuNPs were employed as a nanocarrier for the delivery of microRNA mimics to restore a physiological miRNAs signature in uveal melanoma [206]. In particular, this strategy was used to increase the levels of two tumor suppressor miRNAs, miRNA-34a and miRNA-144, which play a crucial role in EMT inhibition $[207,208]$. Hence, restoring a standard miRNAs profile using AuNPs led to chemosensitivity and cell death [206].

\section{NP-Mediated Toxicology by Modulating EMT}

Despite the potential advantages of the described nanostructures, it is necessary to remember that the use of these nanomedicines may display some toxicity. Interestingly, both the toxicity and the therapeutic effect observed may derive from the modulation of the EMT process (Table 3). 
Table 3. Examples of NP-mediated toxicology by modulating EMT.

\begin{tabular}{|c|c|c|c|c|c|}
\hline Entry & NP & Target Cell Line/Model & Tissue Type & Biological Effect & Refs \\
\hline 1 & AgNPs & BEAS-2B & Bronchial & $\begin{array}{l}\text { Induction in cell migration and invasion; } \\
\text { Induction of mesenchymal phenotype; } \\
\text { Collagene deposition; } \\
\text { Alteration of transcriptomic profile; } \\
\text { Induction of EMT; } \\
\text { Inhibition of apopotisis }\end{array}$ & {$[209,210]$} \\
\hline 3 & $\mathrm{CeO}_{2}$-NPs & $\begin{array}{l}\text { Lung fibroblast } \\
\text { Alveolar type II (ATII) } \\
\text { cells }\end{array}$ & Lung & $\begin{array}{l}\text { Activation of EMT; } \\
\text { Cytotoxicity; } \\
\text { Decreasing proliferation; } \\
\text { Lung fibrosis }\end{array}$ & [212] \\
\hline 6 & $\mathrm{TiO}_{2}-\mathrm{NPs}$ & CD-1 (ICR) female mice & Kidney & $\begin{array}{c}\text { Kidney injury, nephrotoxicity; } \\
\text { Inflammation, fibrosis; } \\
\text { Increasing in EMT and Wnt signaling }\end{array}$ & [218] \\
\hline
\end{tabular}

It has been reported that BEAS-2B human bronchial epithelial cells under chronic exposure to silver nanoparticles undergo an increase of anchorage-independent cell growth, collagen deposition, cell migration, and invasion [209,210]. Also, an antiapoptotic effect and an induction of EMT pathways were observed, indicating that BEAS-2B cells chronically exposed to low dose of AgNPs could acquire some features characteristic of tumorigenic cells $[209,210]$.

Increasing reports showed that treatment with silica nanoparticles (SiNPs) might lead to inflammation, which represents an important co-cause in tumor onset [219]. A recent report demonstrated that BEAS-2B cells co-cultured with human mononuclear (THP-1) cells when treated with benzo[a]pyrene-7, 8-dihydrodiol-9, 10-epoxide (BPDE) and spherical SiNPs showed activation of EMT and tumorigenic features [211]. Interestingly, co-treatment of SiNPs and BPDE promoted EMT of BEAS-2B cells via the AKT pathway by inducing the release of SDF-1 from THP-1 cells [211]. Although direct carcinogenesis by SiNPs treatment has not been proven so far, this evidence suggests that SiNPs can promote tumor development when combined with BPDE and assume relevance for explaining the high incidence of lung cancer upon environmental exposure.

Several studies suggest that cerium oxide nanoparticles $\left(\mathrm{CeO}_{2}-\mathrm{NPs}\right)$ from diesel engines represent a serious health concern since long-term exposure to these nanocompounds may lead to inflammation and lung fibrosis [220,221].

$\mathrm{CeO}_{2}$-NPs-induced lung fibrosis has been shown to be linked with the accumulation of these nanomaterials in the lungs, the induction of inflammatory and fibrotic cytokines, for example, TGF $\beta 1$, and the dysregulation of the mediators playing a pivotal role in ECM remodeling [220].

Recently, it was reported that $\mathrm{CeO}_{2}-\mathrm{NPs}$ exposure can induce lung fibroblast activity and induce EMT in alveolar type II (ATII) cells isolated from $\mathrm{CeO}_{2}-\mathrm{NPs}$-exposed rats playing a pivotal role in lung fibrosis [212].

Carbon nanotubes (CNTs) are of great interest due to their peculiar chemical and physical properties and their potential applications in engineering, industry, and medicine. However, with the increase of CNT production and utilization, the adverse health effects of chronic exposure to these nanomaterials have emerged. Particularly, chronic inflammation, fibrosis, and carcinogenesis have been observed in human lung epithelial cells after long-term exposure to CNTs [222-224]. 
Interestingly, several studies report that exposure to CNTs can induce EMT and fibrosis, leading to oncogenic transformation, tumor progression, and metastasis in bronchial, mesothelial, and lung epithelial cells [213-217].

Although the toxicity of the majority of nanomaterials is related mainly to the respiratory system, toxicity towards other tissues was also reported.

For instance, chronic exposure to $\mathrm{TiO}_{2}$-NPs led to substantial renal injury in mouse kidney [225], which was attributed to chronic renal inflammation and fibrosis [226].

More recent studies linked this fibrotic damage to the activation of Wnt pathway and EMT induction [218].

These and other studies [227-229], indicate that EMT modulation mediated by certain nanomaterials can potentially represent a risk for the respiratory system. However, the involvement and nature of EMT activation in the pathogenesis of the above-described diseases need further investigation.

\section{Conclusions}

EMT induction leads to an extensive reprogramming of the cell proteome implicated in many physio-pathological conditions, including tumor transformation and metastasis.

There are many pieces of evidence suggesting that targeting EMT may be exploited as a therapeutic strategy itself, or to enhance the efficacy of chemotherapy drugs [3-5]. In this regard, nanostructures can be employed to modulate EMT or to deliver therapeutic molecules against EMT-related pathways.

Thus, the application of these functional nanomaterials results in apoptosis induction, inhibition of cell invasion and migration, and increased chemosensitivity and therapeutic efficacy.

Despite these benefits reported, it should be kept in mind that, in some cases, nanomaterials may overstimulate EMT in healthy tissues leading to dangerous effects, including inflammation, fibrosis, and neoplastic transformation.

In conclusion, the findings summarized in this review suggest that EMT inhibition with nanoparticle-based strategies may interfere with various steps of tumor transformation, providing an effective therapeutic approach against cancer.

Funding: This work was partially supported by the Spanish Ministry of Economy and Competitiveness (SAF2017-87305-R) and Comunidad de Madrid (IND2017/IND-7809). IMDEA Nanociencia acknowledges support from the 'Severo Ochoa' Programme for Centres of Excellence in R\&D (MINECO, Grant SEV-2016-0686).

Conflicts of Interest: The authors declare no conflict of interest.

\section{References}

1. Nieto, M.A.; Huang, R.Y.Y.J.; Jackson, R.A.A.; Thiery, J.P.P. EMT: 2016. Cell 2016, 166, 21-45. [CrossRef]

2. Fischer, K.R.; Durrans, A.; Lee, S.; Sheng, J.; Li, F.; Wong, S.T.C.; Choi, H.; El Rayes, T.; Ryu, S.; Troeger, J.; et al. Epithelial-to-mesenchymal transition is not required for lung metastasis but contributes to chemoresistance. Nature 2015, 527, 472-476. [CrossRef]

3. Du, B.; Shim, J.S. Targeting epithelial-mesenchymal transition (EMT) to overcome drug resistance in cancer. Molecules 2016, 21, 965. [CrossRef] [PubMed]

4. Elaskalani, O.; Razak, N.B.A.; Falasca, M.; Metharom, P. Epithelial-mesenchymal transition as a therapeutic target for overcoming chemoresistance in pancreatic cancer. World J. Gastrointest. Oncol. 2017, 9, 37. [CrossRef] [PubMed]

5. Davis, F.M.; Stewart, T.A.; Thompson, E.W.; Monteith, G.R. Targeting EMT in cancer: Opportunities for pharmacological intervention. Trends Pharmacol. Sci. 2014, 35, 479-488. [CrossRef] [PubMed]

6. DeVita, V.T.; Chu, E. A history of cancer chemotherapy. Cancer Res. 2008, 68, 8643-8653. [CrossRef]

7. Sinha, R. Nanotechnology in cancer therapeutics: bioconjugated nanoparticles for drug delivery. Mol. Cancer Ther. 2006, 5, 1909-1917. [CrossRef]

8. Lu, Y.; Sun, W.; Gu, Z. Stimuli-responsive nanomaterials for therapeutic protein delivery. J. Control. Release 2014, 194, 1-19. [CrossRef] 
9. Patra, J.K.; Das, G.; Fraceto, L.F.; Campos, E.V.R.; Rodriguez-Torres, M.D.P.; Acosta-Torres, L.S.; Diaz-Torres, L.A.; Grillo, R.; Swamy, M.K.; Sharma, S.; et al. Nano based drug delivery systems: Recent developments and future prospects 10 Technology 1007 Nanotechnology 03 Chemical Sciences 0306 Physical Chemistry (incl. Structural) 03 Chemical Sciences 0303 Macromolecular and Materials Chemistry 11 Medical and He. J. Nanobiotechnol. 2018, 16, 71. [CrossRef]

10. Rodzinski, A.; Guduru, R.; Liang, P.; Hadjikhani, A.; Stewart, T.; Stimphil, E.; Runowicz, C.; Cote, R.; Altman, N.; Datar, R.; et al. Targeted and controlled anticancer drug delivery and release with magnetoelectric nanoparticles. Sci. Rep. 2016, 6, 20867. [CrossRef]

11. Aftab, S.; Shah, A.; Nadhman, A.; Kurbanoglu, S.; Aysıl Ozkan, S.; Dionysiou, D.D.; Shukla, S.S.; Aminabhavi, T.M. Nanomedicine: An effective tool in cancer therapy. Int. J. Pharm. 2018, 540, 132-149. [CrossRef] [PubMed]

12. Greenburg, G.; Hay, E.D. Epithelia suspended in collagen gels can lose polarity and express characteristics of migrating mesenchymal cells. J. Cell Biol. 1982, 95, 333-339. [CrossRef] [PubMed]

13. Brabletz, T.; Kalluri, R.; Nieto, M.A.; Weinberg, R.A. EMT in cancer. Nat. Rev. Cancer 2018, 18, $128-134$. [CrossRef] [PubMed]

14. Tan, E.J.; Olsson, A.K.; Moustakas, A. Reprogramming during epithelial to mesenchymal transition under the control of TGF $\beta$. Cell Adhes. Migr. 2015, 9, 233-246. [CrossRef]

15. Strippoli, R.; Benedicto, I.; Lozano, M.L.P.; Cerezo, A.; López-Cabrera, M.; Del Pozo, M.A. Epithelial-to-mesenchymal transition of peritoneal mesothelial cells is regulated by an ERK/NF- $\mathrm{B} / \mathrm{Snail1}$ pathway. Dis. Model. Mech. 2008, 1, 264-274. [CrossRef]

16. Stanisavljevic, J.; Porta-de-la-Riva, M.; Batlle, R.; de Herreros, A.G.; Baulida, J. The p65 subunit of NF- $k B$ and PARP1 assist Snail1 in activating fibronectin transcription. J. Cell Sci. 2011, 124, 4161-4171. [CrossRef]

17. Clevers, H.; Nusse, R. Wnt/ $\beta$-Catenin Signaling and Disease. Cell 2012, 149, 1192-1205. [CrossRef]

18. Bianchi, A.; Gervasi, M.E.; Bakin, A. Role of $\beta 5$-integrin in epithelial-mesenchymal transition in response to TGF- $\beta$. Cell Cycle 2010, 9, 1647-1659. [CrossRef]

19. Strippoli, R.; Moreno-Vicente, R.; Battistelli, C.; Cicchini, C.; Noce, V.; Amicone, L.; Marchetti, A.; Del Pozo, M.A.; Tripodi, M. Molecular mechanisms underlying peritoneal EMT and fibrosis. Stem Cells Int. 2016, 2016, 3543678. [CrossRef]

20. Gregory, P.A.; Bert, A.G.; Paterson, E.L.; Barry, S.C.; Tsykin, A.; Farshid, G.; Vadas, M.A.; Khew-Goodall, Y.; Goodall, G.J. The miR-200 family and miR-205 regulate epithelial to mesenchymal transition by targeting ZEB1 and SIP1. Nat. Cell Biol. 2008, 10, 593-601. [CrossRef]

21. Maurer, B.; Stanczyk, J.; Jüngel, A.; Akhmetshina, A.; Trenkmann, M.; Brock, M.; Kowal-Bielecka, O.; Gay, R.E.; Michel, B.A.; Distler, J.H.W.; et al. MicroRNA-29, a key regulator of collagen expression in systemic sclerosis. Arthritis Rheum. 2010, 62, 1733-1743. [CrossRef] [PubMed]

22. Zheng, L.; Lin, S.; Lv, C. MiR-26a-5p regulates cardiac fibroblasts collagen expression by targeting ULK1. Sci. Rep. 2018, 8, 2104. [CrossRef] [PubMed]

23. Joo, D.; An, S.; Choi, B.G.; Kim, K.; Choi, Y.M.; Ahn, K.J.; An, I.S.; Cha, H.J. MicroRNA-378b regulates $\alpha$-1-type 1 collagen expression via sirtuin 6 interference. Mol. Med. Rep. 2017, 16, 8520-8524. [CrossRef] [PubMed]

24. Thiery, J.P.; Acloque, H.; Huang, R.Y.J.; Nieto, M.A. Epithelial-mesenchymal transitions in development and disease. Cell 2009, 139, 871-890. [CrossRef] [PubMed]

25. Tsai, J.H.; Donaher, J.L.; Murphy, D.A.; Chau, S.; Yang, J. Spatiotemporal regulation of epithelial-mesenchymal transition is essential for squamous cell carcinoma metastasis. Cancer Cell 2012, 22, 725-736. [CrossRef]

26. Kalluri, R.; Weinberg, R.A. The basics of epithelial-mesenchymal transition. J. Clin. Invest 2009, 119, 1420-1428. [CrossRef]

27. Spaderna, S.; Schmalhofer, O.; Wahlbuhl, M.; Dimmler, A.; Bauer, K.; Sultan, A.; Hlubek, F.; Jung, A.; Strand, D.; Eger, A.; et al. The transcriptional repressor ZEB1 promotes metastasis and loss of cell polarity in cancer. Cancer Res. 2008, 68, 537-544. [CrossRef]

28. Wellner, U.; Schubert, J.; Burk, U.C.; Schmalhofer, O.; Zhu, F.; Sonntag, A.; Waldvogel, B.; Vannier, C.; Darling, D.; Zur Hausen, A.; et al. The EMT-activator ZEB1 promotes tumorigenicity by repressing stemness-inhibiting microRNAs. Nat. Cell Biol. 2009, 11, 1487-1495. [CrossRef] 
29. Zheng, X.; Carstens, J.L.; Kim, J.; Scheible, M.; Kaye, J.; Sugimoto, H.; Wu, C.C.; Lebleu, V.S.; Kalluri, R. Epithelial-to-mesenchymal transition is dispensable for metastasis but induces chemoresistance in pancreatic cancer. Nature 2015, 527, 525-530. [CrossRef]

30. Conde, J.; Doria, G.; Baptista, P. Noble metal nanoparticles applications in cancer. J. Drug Deliv. 2012, 2012, 1-12. [CrossRef]

31. Albanese, A.; Tang, P.S.; Chan, W.C.W. The effect of nanoparticle size, shape, and surface chemistry on biological systems. Annu. Rev. Biomed. Eng. 2012, 14, 1-16. [CrossRef] [PubMed]

32. Liu, Y.; Solomon, M.; Achilefu, S. Perspectives and potential applications of nanomedicine in breastand prostate cancer. Med. Res. Rev. 2013, 33, 3-32. [CrossRef]

33. Cho, K.; Wang, X.; Nie, S.; Chen, Z.G.; Shin, D.M. Therapeutic nanoparticles for drug delivery in cancer. Clin. Cancer Res. 2008, 14, 1310-1316. [CrossRef] [PubMed]

34. Wicki, A.; Witzigmann, D.; Balasubramanian, V.; Huwyler, J. Nanomedicine in cancer therapy: Challenges, opportunities, and clinical applications. J. Control. Release 2015, 200, 138-157. [CrossRef] [PubMed]

35. Tran, S.; DeGiovanni, P.-J.; Piel, B.; Rai, P. Cancer nanomedicine: a review of recent success in drug delivery. Clin. Transl. Med. 2017, 6, 44. [CrossRef] [PubMed]

36. Sun, T.; Zhang, Y.S.; Pang, B.; Hyun, D.C.; Yang, M.; Xia, Y. Engineered nanoparticles for drug delivery in cancer therapy. Angew. Chemie Int. Ed. 2014, 53, 12320-12364. [CrossRef] [PubMed]

37. Partha, R.; Lackey, M.; Hirsch, A.; Casscells, S.W.; Conyers, J.L. Self assembly of amphiphilic C60 fullerene derivatives into nanoscale supramolecular structures. J. Nanobiotechnology 2007, 5, 6. [CrossRef]

38. Partha, R.; Mitchell, L.R.; Lyon, J.L.; Joshi, P.P.; Conyers, J.L. Buckysomes: Fullerene-based nanocarriers for hydrophobic molecule delivery. ACS Nano 2008, 2, 1950-1958. [CrossRef]

39. Yang, W.; Thordarson, P.; Gooding, J.J.; Ringer, S.P.; Braet, F. Carbon nanotubes for biological and biomedical applications. Nanotechnology 2007, 18, 412001. [CrossRef]

40. Williams, K.A.; Veenhuizen, P.T.M.; De la Torre, B.G.; Eritja, R.; Dekker, C. Nanotechnology: Carbon nanotubes with DNA recognition. Nature 2002, 420, 761. [CrossRef]

41. Matsumura, Y.; Kataoka, K. Preclinical and clinical studies of anticancer agent-incorporating polymer micelles. Cancer Sci. 2009, 100, 572-579. [CrossRef] [PubMed]

42. Dreaden, E.C.; Alkilany, A.M.; Huang, X.; Murphy, C.J.; El-Sayed, M.A. The golden age: Gold nanoparticles for biomedicine. Chem. Soc. Rev. 2012, 41, 2740-2779. [CrossRef] [PubMed]

43. Bhattacharya, R.; Mukherjee, P. Biological properties of "naked" metal nanoparticles. Adv. Drug Deliv. Rev. 2008, 60, 1289-1306. [CrossRef] [PubMed]

44. Jain, S.; Hirst, D.G.; O'Sullivan, J.M. Gold nanoparticles as novel agents for cancer therapy. Br. J. Radiol. 2012, 85, 101-113. [CrossRef] [PubMed]

45. Oh, J.; Feldman, M.D.; Kim, J.; Condit, C.; Emelianov, S.; Milner, T.E. Detection of magnetic nanoparticles in tissue using magneto-motive ultrasound. Nanotechnology 2006, 17, 4183-4190. [CrossRef] [PubMed]

46. Hong, H.; Shi, J.; Yang, Y.; Zhang, Y.; Engle, J.W.; Nickles, R.J.; Wang, X.; Cai, W. Cancer-targeted optical imaging with fluorescent zinc oxide nanowires. Nano Lett. 2011, 11, 3744-3750. [CrossRef]

47. Pagliari, F.; Mandoli, C.; Forte, G.; Magnani, E.; Pagliari, S.; Nardone, G.; Licoccia, S.; Minieri, M.; Di Nardo, P.; Traversa, E. Cerium oxide nanoparticles protect cardiac progenitor cells from oxidative stress. ACS Nano 2012, 6, 3767-3775. [CrossRef]

48. Arvizo, R.R.; Saha, S.; Wang, E.; Robertson, J.D.; Bhattacharya, R.; Mukherjee, P. Inhibition of tumor growth and metastasis by a self-therapeutic nanoparticle. Proc. Natl. Acad. Sci. USA 2013, 110, 6700-6705. [CrossRef]

49. Xiong, X.; Arvizo, R.R.; Saha, S.; Robertson, D.J.; McMeekin, S.; Bhattacharya, R.; Mukherjee, P. Sensitization of ovarian cancer cells to cisplatin by gold nanoparticles. Oncotarget 2014, 5, 6453-6465. [CrossRef]

50. Huai, Y.; Zhang, Y.; Xiong, X.; Das, S.; Bhattacharya, R.; Mukherjee, P. Gold nanoparticles sensitize pancreatic cancer cells to gemcitabine. Cell Stress 2019, 3, 267-279. [CrossRef]

51. Li, W.; Li, X.; Liu, S.; Yang, W.; Pan, F.; Yang, X.-Y.; Du, B.; Qin, L.; Pan, Y. Gold nanoparticles attenuate metastasis by tumor vasculature normalization and epithelial-Mesenchymal transition inhibition. Int. J. Nanomed. 2017, 12, 3509-3520. [CrossRef] [PubMed]

52. Wu, Y.; Ali, M.R.K.; Dong, B.; Han, T.; Chen, K.; Chen, J.; Tang, Y.; Fang, N.; Wang, F.; El-Sayed, M.A. Gold nanorod photothermal therapy alters cell junctions and actin network in inhibiting cancer cell collective migration. ACS Nano 2018, 12, 9279-9290. [CrossRef] 
53. Kaushik, N.K.; Kaushik, N.; Yoo, K.C.; Uddin, N.; Kim, J.S.; Lee, S.J.; Choi, E.H. Low doses of PEG-coated gold nanoparticles sensitize solid tumors to cold plasma by blocking the PI3K/AKT-driven signaling axis to suppress cellular transformation by inhibiting growth and EMT. Biomaterials 2016, 87, 118-130. [CrossRef] [PubMed]

54. Li, X.; Song, L.; Hu, X.; Liu, C.; Shi, J.; Wang, H.; Zhan, L.; Song, H. Inhibition of epithelial-mesenchymal transition and tissue regeneration by waterborne titanium dioxide nanoparticles. ACS Appl. Mater. Interfaces 2018, 10, 3449-3458. [CrossRef]

55. Peng, F.; Tee, J.K.; Setyawati, M.I.; Ding, X.; Yeo, H.L.A.; Tan, Y.L.; Leong, D.T.; Ho, H.K. Inorganic nanomaterials as highly efficient inhibitors of cellular hepatic fibrosis. ACS Appl. Mater. Interfaces 2018, 10, 31938-31946. [CrossRef] [PubMed]

56. Wahab, R.; Kaushik, N.; Khan, F.; Kaushik, N.K.; Choi, E.H.; Musarrat, J.; Al-Khedhairy, A.A. Self-styled ZnO nanostructures promotes the cancer cell damage and supresses the epithelial phenotype of glioblastoma. Sci. Rep. 2016, 6, 1-13. [CrossRef]

57. Verma, R.K.; Yu, W.; Shrivastava, A.; Shankar, S.; Srivastava, R.K. $\alpha$-Mangostin-encapsulated PLGA nanoparticles inhibit pancreatic carcinogenesis by targeting cancer stem cells in human, and transgenic (Kras G12D, and Kras G12D/tp53R270H) mice. Sci. Rep. 2016, 6, 1-13. [CrossRef]

58. Verma, R.K.; Yu, W.; Singh, S.P.; Shankar, S.; Srivastava, R.K. Anthothecol-encapsulated PLGA nanoparticles inhibit pancreatic cancer stem cell growth by modulating sonic hedgehog pathway. Nanomed. Nanotechnol. Biol. Med. 2015, 11, 2061-2070. [CrossRef]

59. Das, S.; Mukherjee, P.; Chatterjee, R.; Jamal, Z.; Chatterji, U. Enhancing chemosensitivity of breast cancer stem cells by downregulating SOX2 and ABCG2 using wedelolactone-encapsulated nanoparticles. Mol. Cancer Ther. 2019, 18, 680-692. [CrossRef]

60. Daman, Z.; Faghihi, H.; Montazeri, H. Salinomycin nanoparticles interfere with tumor cell growth and the tumor microenvironment in an orthotopic model of pancreatic cancer. Drug Dev. Ind. Pharm. 2018, 44, 1434-1442. [CrossRef]

61. Sousa, C.; Gouveia, L.F.; Kreutzer, B.; Silva-Lima, B.; Maphasa, R.E.; Dube, A.; Videira, M. Polymeric micellar formulation enhances antimicrobial and anticancer properties of salinomycin. Pharm. Res. 2019, 36, 83. [CrossRef] [PubMed]

62. Sunil Gowda, S.N.; Rajasowmiya, S.; Vadivel, V.; Banu Devi, S.; Celestin Jerald, A.; Marimuthu, S.; Devipriya, N. Gallic acid-coated sliver nanoparticle alters the expression of radiation-induced epithelial-mesenchymal transition in non-small lung cancer cells. Toxicol. In Vitro 2018, 52, $170-177$. [CrossRef] [PubMed]

63. Kumari, M.; Ray, L.; Purohit, M.P.; Patnaik, S.; Pant, A.B.; Shukla, Y.; Kumar, P.; Gupta, K.C. Curcumin loading potentiates the chemotherapeutic efficacy of selenium nanoparticles in HCT116 cells and Ehrlich's ascites carcinoma bearing mice. Eur. J. Pharm. Biopharm. 2017, 117, 346-362. [CrossRef] [PubMed]

64. Kumari, M.; Purohit, M.P.; Patnaik, S.; Shukla, Y.; Kumar, P.; Gupta, K.C. Curcumin loaded selenium nanoparticles synergize the anticancer potential of doxorubicin contained in self-assembled, cell receptor targeted nanoparticles. Eur. J. Pharm. Biopharm. 2018, 130, 185-199. [CrossRef] [PubMed]

65. Balakrishnan, S.; Bhat, F.A.; Raja Singh, P.; Mukherjee, S.; Elumalai, P.; Das, S.; Patra, C.R.; Arunakaran, J. Gold nanoparticle-conjugated quercetin inhibits epithelial-mesenchymal transition, angiogenesis and invasiveness via EGFR/VEGFR-2-mediated pathway in breast cancer. Cell Prolif. 2016, 49, 678-697. [CrossRef]

66. Zheng, N.G.; Mo, S.J.; Li, J.P.; Wu, J.L. Anti-CSC effects in human esophageal squamous cell carcinomas and Eca109/9706 cells induced by nanoliposomal quercetin alone or combined with CD 133 antiserum. Asian Pac. J. Cancer Prev. 2014, 15, 8679-8684. [CrossRef]

67. Fan, J.X.; Zheng, D.W.; Rong, L.; Zhu, J.Y.; Hong, S.; Li, C.; Xu, Z.S.; Cheng, S.X.; Zhang, X.Z. Targeting epithelial-mesenchymal transition: Metal organic network nano-complexes for preventing tumor metastasis. Biomaterials 2017, 139, 116-126. [CrossRef]

68. Wang, Z.; Liang, P.; He, X.; Wu, B.; Liu, Q.; Xu, Z.; Wu, H.; Liu, Z.; Qian, Y.; Wang, S.; et al. Etoposide loaded layered double hydroxide nanoparticles reversing chemoresistance and eradicating human glioma stem cells in vitro and in vivo. Nanoscale 2018, 10, 13106-13121. [CrossRef]

69. Guo, Z.; Li, W.; Yuan, Y.; Zheng, K.; Tang, Y.; Ma, K.; Cui, C.; Wang, L.; He, B.; Zhang, Q. Improvement of chemosensitivity and inhibition of migration via targeting tumor epithelial-to-mesenchymal transition cells by ADH-1-modified liposomes. Drug Deliv. 2018, 25, 112-121. [CrossRef] 
70. Li, W.; Guo, Z.; Zheng, K.; Ma, K.; Cui, C.; Wang, L.; Yuan, Y.; Tang, Y. Dual targeting mesoporous silica nanoparticles for inhibiting tumour cell invasion and metastasis. Int. J. Pharm. 2017, 534, 71-80. [CrossRef]

71. Guo, Z.; Zheng, K.; Tan, Z.; Liu, Y.; Zhao, Z.; Zhu, G.; Ma, K.; Cui, C.; Wang, L.; Kang, T. Overcoming drug resistance with functional mesoporous titanium dioxide nanoparticles combining targeting, drug delivery and photodynamic therapy. J. Mater. Chem. B 2018, 6, 7750-7759. [CrossRef]

72. Agarwalla, P.; Mukherjee, S.; Sreedhar, B.; Banerjee, R. Glucocorticoid receptor-mediated delivery of nano gold-withaferin conjugates for reversal of epithelial-to-mesenchymal transition and tumor regression. Nanomedicine 2016, 11, 2529-2546. [CrossRef] [PubMed]

73. Huang, Y.; Zhou, B.; Luo, H.; Mao, J.; Huang, Y.; Zhang, K.; Mei, C.; Yan, Y.; Jin, H.; Gao, J.; et al. ZnAs@SiO 2 nanoparticles as a potential anti-tumor drug for targeting stemness and epithelial-mesenchymal transition in hepatocellular carcinoma via SHP-1/JAK2/STAT3 signaling. Theranostics 2019, 9, 4391-4408. [CrossRef] [PubMed]

74. Lu, Y.; Liang, Y.; Zheng, X.; Deng, X.; Huang, W.; Zhang, G. EVI1 promotes epithelial-to-mesenchymal transition, cancer stem cell features and chemo-/radioresistance in nasopharyngeal carcinoma. J. Exp. Clin. Cancer Res. 2019, 38, 1-17. [CrossRef]

75. Shen, Y.A.; Lan, K.L.; Chang, C.H.; Lin, L.T.; He, C.L.; Chen, P.H.; Lee, T.W.; Lee, Y.J.; Chuang, C.M. Intraperitoneal 188Re-Liposome delivery switches ovarian cancer metabolism from glycolysis to oxidative phosphorylation and effectively controls ovarian tumour growth in mice. Radiother. Oncol. 2016, 119, 282-290. [CrossRef]

76. Lin, L.T.; Chang, C.Y.; Chang, C.H.; Wang, H.E.; Chiou, S.H.; Liu, R.S.; Lee, T.W.; Lee, Y.J. Involvement of let-7 microRNA for the therapeutic effects of Rhenium-188-embedded liposomal nanoparticles on orthotopic human head and neck cancer model. Oncotarget 2016, 7, 65782-65796. [CrossRef]

77. Chang, C.-Y.; Chen, C.-C.; Lin, L.-T.; Chang, C.-H.; Chen, L.-C.; Wang, H.-E.; Lee, T.-W.; Lee, Y.-J. PEGylated liposome-encapsulated rhenium-188 radiopharmaceutical inhibits proliferation and epithelial-mesenchymal transition of human head and neck cancer cells in vivo with repeated therapy. Cell Death Discov. 2018, 4, 100. [CrossRef]

78. Jin, H.; He, Y.; Zhao, P.; Hu, Y.; Tao, J.; Chen, J.; Huang, Y. Targeting lipid metabolism to overcome EMT-associated drug resistance via integrin $\beta 3 / F A K$ pathway and tumor-associated macrophage repolarization using legumain-activatable delivery. Theranostics 2019, 9, 265-278. [CrossRef]

79. Sadreddini, S.; Safaralizadeh, R.; Baradaran, B.; Aghebati-Maleki, L.; Hosseinpour-Feizi, M.A.; Shanehbandi, D.; Jadidi-Niaragh, F.; Sadreddini, S.; Kafil, H.S.; Younesi, V.; et al. Chitosan nanoparticles as a dual drug/siRNA delivery system for treatment of colorectal cancer. Immunol. Lett. 2017, 181, 79-86. [CrossRef]

80. Afkham, A.; Aghebati-Maleki, L.; Siahmansouri, H.; Sadreddini, S.; Ahmadi, M.; Dolati, S.; Afkham, N.M.; Akbarzadeh, P.; Jadidi-Niaragh, F.; Younesi, V.; et al. Chitosan (CMD)-mediated co-delivery of SN38 and Snail-specific siRNA as a useful anticancer approach against prostate cancer. Pharm. Rep. 2018, 70, 418-425. [CrossRef]

81. Seifi-Najmi, M.; Hajivalili, M.; Safaralizadeh, R.; Sadreddini, S.; Esmaeili, S.; Razavi, R.; Ahmadi, M.; Mikaeili, H.; Baradaran, B.; Shams-Asenjan, K.; et al. SiRNA/DOX lodeded chitosan based nanoparticles: Development, characterization and in vitro evaluation on A549 lung cancer cell line. Cell. Mol. Biol. 2016, 62, 87-94. [PubMed]

82. Fang, S.; Wu, L.; Li, M.; Yi, H.; Gao, G.; Sheng, Z.; Gong, P.; Ma, Y.; Cai, L. ZEB1 knockdown mediated using polypeptide cationic micelles inhibits metastasis and effects sensitization to a chemotherapeutic drug for cancer therapy. Nanoscale 2014, 6, 10084-10094. [CrossRef] [PubMed]

83. Shahin, S.A.; Wang, R.; Simargi, S.I.; Contreras, A.; Parra Echavarria, L.; Qu, L.; Wen, W.; Dellinger, T.; Unternaehrer, J.; Tamanoi, F.; et al. Hyaluronic acid conjugated nanoparticle delivery of siRNA against TWIST reduces tumor burden and enhances sensitivity to cisplatin in ovarian cancer. Nanomed. Nanotechnol. Biol. Med. 2018, 14, 1381-1394. [CrossRef] [PubMed]

84. Roberts, C.M.; Shahin, S.A.; Wen, W.; Finlay, J.B.; Dong, J.; Wang, R.; Dellinger, T.H.; Zink, J.I.; Tamanoi, F.; Glackin, C.A. Nanoparticle delivery of siRNA against TWIST to reduce drug resistance and tumor growth in ovarian cancer models. Nanomed. Nanotechnol. Biol. Med. 2017, 13, 965-976. [CrossRef] 
85. Finlay, J.; Roberts, C.M.; Dong, J.; Zink, J.I.; Tamanoi, F.; Glackin, C.A. Mesoporous silica nanoparticle delivery of chemically modified siRNA against TWIST1 leads to reduced tumor burden. Nanomed. Nanotechnol. Biol. Med. 2015, 11, 1657-1666. [CrossRef]

86. Zhuo, X.; Chang, A.; Huang, C.; Yang, L.; Zhao, H.; Wu, Y.; Zhou, Q. Nanoparticle-mediated down-regulation of TWIST increases radiosensitivity of nasopharyngeal carcinoma cells via ERK pathway. Am. J. Cancer Res. 2015, 5, 1571-1579.

87. Finlay, J.; Roberts, C.M.; Lowe, G.; Loeza, J.; Rossi, J.J.; Glackin, C.A. RNA-based TWIST1 inhibition via dendrimer complex to reduce breast cancer cell metastasis. Biomed Res. Int. 2015, 2015, 382745. [CrossRef]

88. Wang, B.; Ding, Y.; Zhao, X.; Han, X.; Yang, N.; Zhang, Y.; Zhao, Y.; Zhao, X.; Taleb, M.; Miao, Q.R.; et al. Delivery of small interfering RNA against Nogo-B receptor via tumor-acidity responsive nanoparticles for tumor vessel normalization and metastasis suppression. Biomaterials 2018, 175, 110-122. [CrossRef]

89. Parvani, J.G.; Gujrati, M.D.; Mack, M.A.; Schiemann, W.P.; Lu, Z.R. Silencing $\beta 3$ integrin by targeted ECO/siRNA nanoparticles inhibits EMT and metastasis of triple-negative breast cancer. Cancer Res. 2015, 75, 2316-2325. [CrossRef]

90. Vaidya, A.M.; Sun, Z.; Ayat, N.; Schilb, A.; Liu, X.; Jiang, H.; Sun, D.; Scheidt, J.; Qian, V.; He, S.; et al. Systemic delivery of tumor-targeting siRNA nanoparticles against an oncogenic lncRNA facilitates effective triple-negative breast cancer therapy. Bioconjug. Chem. 2019, 30, 907-919. [CrossRef]

91. Sureban, S.M.; May, R.; Mondalek, F.G.; Qu, D.; Ponnurangam, S.; Pantazis, P.; Anant, S.; Ramanujam, R.P.; Houchen, C.W. Nanoparticle-based delivery of siDCAMKL-1 increases microRNA-144 and inhibits colorectal cancer tumor growth via a Notch-1 dependent mechanism. J. Nanobiotechnol. 2011, 9, 40. [CrossRef] [PubMed]

92. Ma, C.; Shi, L.; Huang, Y.; Shen, L.; Peng, H.; Zhu, X.; Zhou, G. Nanoparticle delivery of Wnt-1 siRNA enhances photodynamic therapy by inhibiting epithelial-mesenchymal transition for oral cancer. Biomater. Sci. 2017, 5, 494-501. [CrossRef] [PubMed]

93. Ma, Y.; Zhang, X.; Xu, X.; Shen, L.; Yao, Y.; Yang, Z.; Liu, P. STAT3 decoy oligodeoxynucleotides-loaded solid lipid nanoparticles induce cell death and inhibit invasion in ovarian cancer cells. PLoS ONE 2015, 10, e0124924. [CrossRef] [PubMed]

94. Suresh, D.; Zambre, A.; Mukherjee, S.; Ghoshdastidar, S.; Jiang, Y.; Joshi, T.; Upendran, A.; Kannan, R. Silencing AXL by covalent siRNA-gelatin-antibody nanoconjugate inactivates mTOR/EMT pathway and stimulates 553 for TKI sensitization in NSCLC. Nanomed. Nanotechnol. Biol. Med. 2019, 20, 102007. [CrossRef]

95. Li, Y.; Chen, Y.; Li, J.; Zhang, Z.; Huang, C.; Lian, G.; Yang, K.; Chen, S.; Lin, Y.; Wang, L.; et al. Co-delivery of microRNA-21 antisense oligonucleotides and gemcitabine using nanomedicine for pancreatic cancer therapy. Cancer Sci. 2017, 108, 1493-1503. [CrossRef]

96. Hong, S.-T.; Lin, H.; Wang, C.-S.; Chang, C.-H.; Lin, A.M.-Y.; Yang, J.C.-H.; Lo, Y.-L. Improving the anticancer effect of afatinib and microRNA by using lipid polymeric nanoparticles conjugated with dual $\mathrm{pH}$-responsive and targeting peptides. J. Nanobiotechnol. 2019, 17, 89. [CrossRef]

97. Liu, Q.; Li, R.T.; Qian, H.Q.; Wei, J.; Xie, L.; Shen, J.; Yang, M.; Qian, X.P.; Yu, L.X.; Jiang, X.Q.; et al. Targeted delivery of miR-200c/DOC to inhibit cancer stem cells and cancer cells by the gelatinases-stimuli nanoparticles. Biomaterials 2013, 34, 7191-7203. [CrossRef]

98. Connor, E.E.; Mwamuka, J.; Gole, A.; Murphy, C.J.; Wyatt, M.D. Gold nanoparticles are taken up by human cells but do not cause acute cytotoxicity. Small 2005, 1, 325-327. [CrossRef]

99. Popat, K.C.; Eltgroth, M.; LaTempa, T.J.; Grimes, C.A.; Desai, T.A. Titania nanotubes: A novel platform for drug-eluting coatings for medical implants? Small 2007, 3, 1878-1881. [CrossRef]

100. Arvizo, R.; Bhattacharya, R.; Mukherjee, P. Gold nanoparticles: Opportunities and challenges in nanomedicine. Expert Opin. Drug Deliv. 2010, 7, 753-763. [CrossRef]

101. Bañobre-López, M.; Teijeiro, A.; Rivas, J. Magnetic nanoparticle-based hyperthermia for cancer treatment. Rep. Pract. Oncol. Radiother. 2013, 18, 397-400. [CrossRef] [PubMed]

102. Tang, Y.L.; Jiang, J.; Liu, J.; Zheng, M.; He, Y.W.; Chen, W.; Fan, Y.L.; Chen, Q.M.; Liao, C.H.; Liang, X.H. Hyperthermia inhibited the migration of tongue squamous cell carcinoma through TWIST2. J. Oral Pathol. Med. 2015, 44, 337-344. [CrossRef] [PubMed]

103. Jin, H.; Zhao, Y.; Zhang, S.; Yang, J.; Zhang, X.; Ma, S. Hyperthermia inhibits the motility of gemcitabine-resistant pancreatic cancer PANC-1 cells through the inhibition of epithelial-mesenchymal transition. Mol. Med. Rep. 2018, 17, 7274-7280. [CrossRef] [PubMed] 
104. Kimura-Tsuchiya, R.; Ishikawa, T.; Kokura, S.; Mizushima, K.; Adachi, S.; Okajima, M.; Matsuyama, T.; Okayama, T.; Sakamoto, N.; Katada, K.; et al. The inhibitory effect of heat treatment against epithelial-mesenchymal transition (EMT) in human pancreatic adenocarcinoma cell lines. J. Clin. Biochem. Nutr. 2014, 55, 56-61. [CrossRef]

105. Yuan, G.-J. Hyperthermia inhibits hypoxia-induced epithelial-mesenchymal transition in HepG2 hepatocellular carcinoma cells. World J. Gastroenterol. 2012, 18, 4781. [CrossRef]

106. Xu, X.M.; Yuan, G.J.; Li, Q.W.; Shan, S.L.; Jiang, S. Hyperthermia inhibits transforming growth factor beta-induced epithelial-mesenchymal transition (EMT) in HepG2 hepatocellular carcinoma cells. Hepatogastroenterology 2012, 59, 2059-2063.

107. Huang, X.; Jain, P.K.; El-Sayed, I.H.; El-Sayed, M.A. Plasmonic photothermal therapy (PPTT) using gold nanoparticles. Lasers Med. Sci. 2008, 23, 217-228. [CrossRef]

108. Çeşmeli, S.; Biray Avci, C. Application of titanium dioxide $\left(\mathrm{TiO}_{2}\right)$ nanoparticles in cancer therapies. J. Drug Target. 2019, 27, 762-766. [CrossRef]

109. Namvar, F.; Rahman, H.S.; Mohamad, R.; Azizi, S.; Tahir, P.M.; Chartrand, M.S.; Yeap, S.K. Cytotoxic effects of biosynthesized zinc oxide nanoparticles on murine cell lines. Evid. Based Complement. Altern. Med. 2015, 2015, 593014. [CrossRef]

110. Wahab, R.; Siddiqui, M.A.; Saquib, Q.; Dwivedi, S.; Ahmad, J.; Musarrat, J.; Al-Khedhairy, A.A.; Shin, H.S. $\mathrm{ZnO}$ nanoparticles induced oxidative stress and apoptosis in HepG2 and MCF-7 cancer cells and their antibacterial activity. Colloids Surf. B Biointerfaces 2014, 117, 267-276. [CrossRef]

111. Shen, J.; Sun, H.; Xu, P.; Yin, Q.; Zhang, Z.; Wang, S.; Yu, H.; Li, Y. Simultaneous inhibition of metastasis and growth of breast cancer by co-delivery of twist shRNA and paclitaxel using pluronic P85-PEI/TPGS complex nanoparticles. Biomaterials 2013, 34, 1581-1590. [CrossRef] [PubMed]

112. Tang, S.; Yin, Q.; Su, J.; Sun, H.; Meng, Q.; Chen, Y.; Chen, L.; Huang, Y.; Gu, W.; Xu, M.; et al. Inhibition of metastasis and growth of breast cancer by $\mathrm{pH}$-sensitive poly( $\beta$-amino ester) nanoparticles co-delivering two siRNA and paclitaxel. Biomaterials 2015, 48, 1-15. [CrossRef] [PubMed]

113. Hafeez, B.B.; Mustafa, A.; Fischer, J.W.; Singh, A.; Zhong, W.; Shekhani, M.O.; Meske, L.; Havighurst, T.; Kim, K.; Verma, A.K. $\alpha$-mangostin: A dietary antioxidant derived from the pericarp of Garcinia mangostana L. inhibits pancreatic tumor growth in xenograft mouse model. Antioxid. Redox Signal. 2014, 21, 682-699. [CrossRef] [PubMed]

114. Jittiporn, K.; Suwanpradid, J.; Patel, C.; Rojas, M.; Thirawarapan, S.; Moongkarndi, P.; Suvitayavat, W.; Caldwell, R.B. Anti-angiogenic actions of the mangosteen polyphenolic xanthone derivative $\alpha$-mangostin. Microvasc. Res. 2014, 93, 72-79. [CrossRef]

115. Kritsanawong, S.; Innajak, S.; Imoto, M.; Watanapokasin, R. Antiproliferative and apoptosis induction of $\alpha$-mangostin in T47D breast cancer cells. Int. J. Oncol. 2016, 48, 2155-2165. [CrossRef]

116. Shan, T.; Cui, X.; Li, W.; Lin, W.; Lu, H.; Li, Y.; Chen, X.; Wu, T. $\alpha$-Mangostin suppresses human gastric adenocarcinoma cells in vitro via blockade of Stat3 signaling pathway. Acta Pharmacologica Sinica 2014, 35, 1065-1073. [CrossRef]

117. Lee, S.E.; Kim, M.R.; Kim, J.H.; Takeoka, G.R.; Kim, T.W.; Park, B.S. Antimalarial activity of anthothecol derived from Khaya anthotheca (Meliaceae). Phytomedicine 2008, 15, 533-535. [CrossRef]

118. Xu, Q.; Ma, J.; Lei, J.; Duan, W.; Sheng, L.; Chen, X.; Hu, A.; Wang, Z.; Wu, Z.; Wu, E.; et al. $\alpha$-mangostin suppresses the viability and epithelial-mesenchymal transition of pancreatic cancer cells by downregulating the PI3K/Akt pathway. Biomed Res. Int. 2014, 2014, 546353. [CrossRef]

119. Pandey, K.B.; Rizvi, S.I. Plant polyphenols as dietary antioxidants in human health and disease. Oxid. Med. Cell. Longev. 2009, 2, 270-278. [CrossRef]

120. Rezvantalab, S.; Drude, N.I.; Moraveji, M.K.; Güvener, N.; Koons, E.K.; Shi, Y.; Lammers, T.; Kiessling, F. PLGA-based nanoparticles in cancer treatment. Front. Pharm. 2018, 9, 1260. [CrossRef]

121. Sarveswaran, S.; Gautam, S.C.; Ghosh, J. Wedelolactone, a medicinal plant-derived coumestan, induces caspase-dependent apoptosis in prostate cancer cells via downregulation of PKC $\varepsilon$ without inhibiting Akt. Int. J. Oncol. 2012, 41, 2191-2199. [CrossRef] [PubMed]

122. Xu, D.; Lin, T.H.; Yeh, C.R.; Cheng, M.A.; Chen, L.M.; Chang, C.; Yeh, S. The wedelolactone derivative inhibits estrogen receptor-mediated breast, endometrial, and ovarian cancer cells growth. Biomed Res. Int. 2014, 2014. [CrossRef] [PubMed] 
123. Yang, J.; Tao, L.; Liu, B.; You, X.; Zhang, C.; Xie, H.; Li, R. Wedelolactone attenuates pulmonary fibrosis partly through activating AMPK and regulating Raf-MAPKs signaling pathway. Front. Pharm. 2019, 10, 151. [CrossRef] [PubMed]

124. Schenk, M.; Aykut, B.; Teske, C.; Giese, N.A.; Weitz, J.; Welsch, T. Salinomycin inhibits growth of pancreatic cancer and cancer cell migration by disruption of actin stress fiber integrity. Cancer Lett. 2015, 358, 161-169. [CrossRef] [PubMed]

125. Zhang, G.N.; Liang, Y.; Zhou, L.J.; Chen, S.P.; Chen, G.; Zhang, T.P.; Kang, T.; Zhao, Y.P. Combination of salinomycin and gemcitabine eliminates pancreatic cancer cells. Cancer Lett. 2011, 313, 137-144. [CrossRef]

126. Mao, Z.; Wu, Y.; Zhou, J.; Xing, C. Salinomycin reduces epithelial-mesenchymal transition-mediated multidrug resistance by modifying long noncoding RNA HOTTIP expression in gastric cancer cells. Anti-cancer Drugs 2019, 30, 892-899. [CrossRef]

127. Davis, M.E.; Chen, Z.; Shin, D.M. Nanoparticle therapeutics: An emerging treatment modality for cancer. In Nanoscience and Technology: A Collection of Reviews from Nature Journals; Macmillan: London, UK; World Scientific: Singapore, 2009; pp. 239-250. ISBN 9789814287005.

128. Paolini, A.; Curti, V.; Pasi, F.; Mazzini, G.; Nano, R.; Capelli, E. Gallic acid exerts a protective or an anti-proliferative effect on glioma T98G cells via dose-dependent epigenetic regulation mediated by miRNAs. Int. J. Oncol. 2015, 46, 1491-1497. [CrossRef]

129. Ho, H.-H.; Chang, C.-S.; Ho, W.-C.; Liao, S.-Y.; Wu, C.-H.; Wang, C.-J. Anti-metastasis effects of gallic acid on gastric cancer cells involves inhibition of NF- $\mathrm{kB}$ activity and downregulation of PI3K/AKT/small GTPase signals. Food Chem. Toxicol. 2010, 48, 2508-2516. [CrossRef]

130. Chen, H.M.; Wu, Y.C.; Chia, Y.C.; Chang, F.R.; Hsu, H.K.; Hsieh, Y.C.; Chen, C.C.; Yuan, S.S. Gallic acid, a major component of Toona sinensis leaf extracts, contains a ROS-mediated anti-cancer activity in human prostate cancer cells. Cancer Lett. 2009, 286, 161-171. [CrossRef]

131. Jin, L.; Piao, Z.H.; Sun, S.; Liu, B.; Ryu, Y.; Choi, S.Y.; Kim, G.R.; Kim, H.S.; Kee, H.J.; Jeong, M.H. Gallic acid attenuates pulmonary fibrosis in a mouse model of transverse aortic contraction-induced heart failure. Vasc. Pharm. 2017, 99, 74-82. [CrossRef]

132. Cordani, M.; Somoza, Á. Targeting autophagy using metallic nanoparticles: A promising strategy for cancer treatment. Cell. Mol. Life Sci. 2019, 76, 1215-1242. [CrossRef] [PubMed]

133. Liu, Z.; Zhu, Y.Y.; Li, Z.Y.; Ning, S.Q. Evaluation of the efficacy of paclitaxel with curcumin combination in ovarian cancer cells. Oncol. Lett. 2016, 12, 3944-3948. [CrossRef] [PubMed]

134. Paramita, P.; Wardhani, B.W.K.; Wanandi, S.I.; Louisa, M. Curcumin for the prevention of epithelial-mesenchymal transition in endoxifen-treated MCF-7 breast cancer cells. Asian Pac. J. Cancer Prev. 2018, 19, 1243-1249. [PubMed]

135. Jiao, D.; Wang, J.; Lu, W.; Tang, X.; Chen, J.; Mou, H.; Chen, Q. Curcumin inhibited HGF-induced EMT and angiogenesis through regulating c-Met dependent PI3K/Akt/mTOR signaling pathways in lung cancer. Mol. Ther. Oncolytics 2016, 3, 16018. [CrossRef] [PubMed]

136. Zhao, J.L.; Guo, M.Z.; Zhu, J.J.; Zhang, T.; Min, D.Y. Curcumin suppresses epithelial-to-mesenchymal transition of peritoneal mesothelial cells (HMrSV5) through regulation of transforming growth factor-activated kinase 1 (TAK1). Cell. Mol. Biol. Lett. 2019, 24, 32. [CrossRef] [PubMed]

137. Yallapu, M.M.; Jaggi, M.C.; Chauhan, S. Curcumin nanomedicine: A road to cancer therapeutics. Curr. Pharm. Des. 2013, 19, 1994-2010.

138. Kong, L.; Yuan, Q.; Zhu, H.; Li, Y.; Guo, Q.; Wang, Q.; Bi, X.; Gao, X. The suppression of prostate LNCaP cancer cells growth by Selenium nanoparticles through Akt/Mdm2/AR controlled apoptosis. Biomaterials 2011, 32, 6515-6522. [CrossRef]

139. Luo, H.; Wang, F.; Bai, Y.; Chen, T.; Zheng, W. Selenium nanoparticles inhibit the growth of HeLa and MDA-MB-231 cells through induction of S phase arrest. Colloids Surf. B Biointerfaces 2012, 94, 304-308. [CrossRef]

140. Zheng, S.; Li, X.; Zhang, Y.; Xie, Q.; Wong, Y.S.; Zheng, W.; Chen, T. PEG-nanolized ultrasmall selenium nanoparticles overcome drug resistance in hepatocellular carcinoma HepG2 cells through induction of mitochondria dysfunction. Int. J. Nanomed. 2012, 7, 3939-3949.

141. Liu, H.; Jiang, W.; Xie, M. Flavonoids: Recent advances as anticancer drugs. Recent Pat. Anti-cancer Drug Discov. 2010, 5, 152-164. [CrossRef] 
142. Yu, D.; Ye, T.; Xiang, Y.; Shi, Z.; Zhang, J.; Lou, B.; Zhang, F.; Chen, B.; Zhou, M. Quercetin inhibits epithelial-mesenchymal transition, decreases invasiveness and metastasis, and reverses IL-6 induced epithelial-mesenchymal transition, expression of MMP by inhibiting STAT3 signaling in pancreatic cancer cells. Oncol. Targets. Ther. 2017, 10, 4719-4729. [CrossRef] [PubMed]

143. Patel, D.; Sharma, N. Inhibitory effect of quercetin on epithelial to mesenchymal transition in SK-MEL-28 human melanoma cells defined by in vitro analysis on 3D collagen gels. Oncol. Targets. Ther. 2016, 9, 6445-6459. [CrossRef] [PubMed]

144. Hosta-Rigau, L.; Schattling, P.; Teo, B.M.; Lynge, M.E.; Städler, B. Recent progress of liposomes in nanomedicine. J. Mater. Chem. B 2014, 2, 6686-6691. [CrossRef]

145. Chu, C.; Deng, J.; Man, Y.; Qu, Y. Green tea extracts epigallocatechin-3-gallate for different treatments. Biomed Res. Int. 2017, 2017, 5615647. [CrossRef]

146. Li, T.; Zhao, N.; Lu, J.; Zhu, Q.; Liu, X.; Hao, F.; Jiao, X. Epigallocatechin gallate (EGCG) suppresses epithelial-Mesenchymal transition (EMT) and invasion in anaplastic thyroid carcinoma cells through blocking of TGF- $\beta 1 /$ Smad signaling pathways. Bioengineered 2019, 10, 282-291. [CrossRef]

147. Kanlaya, R.; Khamchun, S.; Kapincharanon, C.; Thongboonkerd, V. Protective effect of epigallocatechin-3-gallate (EGCG) via Nrf2 pathway against oxalate-induced epithelial mesenchymal transition (EMT) of renal tubular cells. Sci. Rep. 2016, 6, 30233. [CrossRef]

148. Lu, H.; Meng, X.; Yang, C.S. Enzymology of methylation of tea catechins and inhibition of catechol-O-methyltransferase by (-)-epigallocatechin gallate. Drug Metab. Dispos. 2003, 31, 572-579. [CrossRef]

149. Huo, C.; Wan, S.B.; Lam, W.H.; Li, L.; Wang, Z.; Landis-Piwowar, K.R.; Chen, D.; Dou, Q.P.; Chan, T.H. The challenge of developing green tea polyphenols as therapeutic agents. Inflammopharmacology 2008, 16, 248-252. [CrossRef]

150. Gordaliza, M.; García, P.A.; Miguel Del Corral, J.M.; Castro, M.A.; Gómez-Zurita, M.A. Podophyllotoxin: Distribution, sources, applications and new cytotoxic derivatives. Toxicon 2004, 44, 441-459. [CrossRef]

151. Sonabend, A.M.; Carminucci, A.S.; Amendolara, B.; Bansal, M.; Leung, R.; Lei, L.; Realubit, R.; Li, H.; Karan, C.; Yun, J.; et al. Convection-enhanced delivery of etoposide is effective against murine proneural glioblastoma. Neuro. Oncol. 2014, 16, 1210-1219. [CrossRef]

152. Needle, M.N.; Molloy, P.T.; Geyer, J.R.; Herman-Liu, A.; Belasco, J.B.; Goldwein, J.W.; Sutton, L.; Phillips, P.C. Phase II study of daily oral etoposide in children with recurrent brain tumors and other solid tumors. Med. Pediatr. Oncol. 1997, 29, 28-32. [CrossRef]

153. Eramo, A.; Ricci-Vitiani, L.; Zeuner, A.; Pallini, R.; Lotti, F.; Sette, G.; Pilozzi, E.; Larocca, L.M.; Peschle, C.; De Maria, R. Chemotherapy resistance of glioblastoma stem cells. Cell Death Differ. 2006, 13, 1238-1241. [CrossRef] [PubMed]

154. Liu, G.; Yuan, X.; Zeng, Z.; Tunici, P.; Ng, H.; Abdulkadir, I.R.; Lu, L.; Irvin, D.; Black, K.L.; Yu, J.S. Analysis of gene expression and chemoresistance of $\mathrm{CD}_{133^{+}}$cancer stem cells in glioblastoma. Mol. Cancer 2006, 5, 67 . [CrossRef] [PubMed]

155. Jin, F.; Zhao, L.; Guo, Y.-J.; Zhao, W.-J.; Zhang, H.; Wang, H.-T.; Shao, T.; Zhang, S.-L.; Wei, Y.-J.; Feng, J.; et al. Influence of etoposide on anti-apoptotic and multidrug resistance-associated protein genes in CD133 positive U251 glioblastoma stem-like cells. Brain Res. 2010, 1336, 103-111. [CrossRef]

156. Biasoli, D.; Kahn, S.A.; Cornélio, T.A.; Furtado, M.; Campanati, L.; Chneiweiss, H.; Moura-Neto, V.; Borges, H.L. Retinoblastoma protein regulates the crosstalk between autophagy and apoptosis, and favors glioblastoma resistance to etoposide. Cell Death Dis. 2013, 4, e767. [CrossRef]

157. Augustine, C.K.; Yoshimoto, Y.; Gupta, M.; Zipfel, P.A.; Selim, M.A.; Febbo, P.; Pendergast, A.M.; Peters, W.P.; Tyler, D.S. Targeting N-cadherin enhances antitumor activity of cytotoxic therapies in melanoma treatment. Cancer Res. 2008, 68, 3777-3784. [CrossRef]

158. Perotti, A.; Sessa, C.; Mancuso, A.; Noberasco, C.; Cresta, S.; Locatelli, A.; Carcangiu, M.L.; Passera, K.; Braghetti, A.; Scaramuzza, D.; et al. Clinical and pharmacological phase I evaluation of Exherin ${ }^{\mathrm{TM}}$ (ADH-1), a selective anti-N-cadherin peptide in patients with $\mathrm{N}$-cadherin-expressing solid tumours. Ann. Oncol. 2009, 20, 741-745. [CrossRef]

159. Shintani, Y.; Fukumoto, Y.; Chaika, N.; Grandgenett, P.M.; Hollingsworth, M.A.; Wheelock, M.J.; Johnson, K.R. ADH-1 suppresses $\mathrm{N}$-cadherin-dependent pancreatic cancer progression. Int. J. Cancer 2008, 122, 71-77. [CrossRef] 
160. Bledsoe, R.K.; Montana, V.G.; Stanley, T.B.; Delves, C.J.; Apolito, C.J.; McKee, D.D.; Consler, T.G.; Parks, D.J.; Stewart, E.L.; Willson, T.M.; et al. Crystal structure of the glucocorticoid receptor ligand binding domain reveals a novel mode of receptor dimerization and coactivator recognition. Cell 2002, 110, 93-105. [CrossRef]

161. Zhang, L.; Lei, W.; Wang, X.; Tang, Y.; Song, J. Glucocorticoid induces mesenchymal-to-epithelial transition and inhibits TGF- $\beta 1$-induced epithelial-to-mesenchymal transition and cell migration. FEBS Lett. 2010, 584, 4646-4654. [CrossRef]

162. Ferrand, N.; Stragier, E.; Redeuilh, G.; Sabbah, M. Glucocorticoids induce CCN5/WISP-2 expression and attenuate invasion in oestrogen receptor-negative human breast cancer cells. Biochem. J. 2012, 447, 71-79. [CrossRef] [PubMed]

163. Coutinho, A.E.; Chapman, K.E. The anti-inflammatory and immunosuppressive effects of glucocorticoids, recent developments and mechanistic insights. Mol. Cell. Endocrinol. 2011, 335, 2-13. [CrossRef] [PubMed]

164. Kim, J.H.; Hwang, Y.J.; Han, S.H.; Lee, Y.E.; Kim, S.; Kim, Y.J.; Cho, J.H.; Kwon, K.A.; Kim, J.H.; Kim, S.H. Dexamethasone inhibits hypoxia-induced epithelial-mesenchymal transition in colon cancer. World J. Gastroenterol. 2015, 21, 9887-9899. [CrossRef] [PubMed]

165. Jang, Y.H.; Shin, H.S.; Sun Choi, H.; Ryu, E.S.; Jin Kim, M.; Ki Min, S.; Lee, J.H.; Kook Lee, H.; Kim, K.H.; Kang, D.H. Effects of dexamethasone on the TGF- $\beta 1$-induced epithelial-to-mesenchymal transition in human peritoneal mesothelial cells. Lab. Investig. 2013, 93, 194-206. [CrossRef]

166. Bordag, N.; Klie, S.; Jürchott, K.; Vierheller, J.; Schiewe, H.; Albrecht, V.; Tonn, J.C.; Schwartz, C.; Schichor, C.; Selbig, J. Glucocorticoid (dexamethasone)-induced metabolome changes in healthy males suggest prediction of response and side effects. Sci. Rep. 2015, 5, 15954. [CrossRef]

167. Wang, H.; Schaefer, T.; Konantz, M.; Braun, M.; Varga, Z.; Paczulla, A.M.; Reich, S.; Jacob, F.; Perner, S.; Moch, H.; et al. Prominent oncogenic roles of EVI1 in breast carcinoma. Cancer Res. 2017, 77, 2148-2160. [CrossRef]

168. Fan, Z.; He, J.; Fu, T.; Zhang, W.; Yang, G.; Qu, X.; Liu, R.; Lv, L.; Wang, J. Arsenic trioxide inhibits EMT in hepatocellular carcinoma by promoting lncRNA MEG3 via PKM2. Biochem. Biophys. Res. Commun. 2019, 513, 834-840. [CrossRef]

169. Kim, S.H.; Yoo, H.S.; Joo, M.K.; Kim, T.; Park, J.-J.; Lee, B.J.; Chun, H.J.; Lee, S.W.; Bak, Y.-T. Arsenic trioxide attenuates STAT-3 activity and epithelial-mesenchymal transition through induction of SHP-1 in gastric cancer cells. BMC Cancer 2018, 18, 150. [CrossRef]

170. Akhtar, A.; Wang, S.X.; Ghali, L.; Bell, C.; Wen, X. Recent advances in arsenic trioxide encapsulated nanoparticles as drug delivery agents to solid cancers. J. Biomed. Res. 2016, 31, 177-188.

171. Argyrou, M.; Valassi, A.; Andreou, M.; Lyra, M. Rhenium-188 production in hospitals, by W-188/Re-188 generator, for easy use in radionuclide therapy. Int. J. Mol. Imaging 2013, 2013, 1-7. [CrossRef]

172. Zhang, H.; Tian, M.; Li, S.; Liu, J.; Tanada, S.; Endo, K. Rhenium-188-HEDP therapy for the palliation of pain due to osseous metastases in lung cancer patients. Cancer Biother. Radiopharm. 2003, 18, 719-726. [CrossRef] [PubMed]

173. Maruyama, K. Intracellular targeting delivery of liposomal drugs to solid tumors based on EPR effects. Adv. Drug Deliv. Rev. 2011, 63, 161-169. [CrossRef] [PubMed]

174. Quijano, E.; Bahal, R.; Ricciardi, A.; Saltzman, W.M.; Glazer, P.M. Therapeutic peptide nucleic acids: Principles, limitations, and opportunities. Yale J. Biol. Med. 2017, 90, 583-598. [PubMed]

175. Caplen, N.J.; Parrish, S.; Imani, F.; Fire, A.; Morgan, R.A. Specific inhibition of gene expression by small double-stranded RNAs in invertebrate and vertebrate systems. Proc. Natl. Acad. Sci. USA 2001, 98, 9742-9747. [CrossRef] [PubMed]

176. De Fougerolles, A.R. Delivery vehicles for small interfering RNA in vivo. Hum. Gene Ther. 2008, 19, $125-132$. [CrossRef] [PubMed]

177. Cano, A.; Pérez-Moreno, M.A.; Rodrigo, I.; Locascio, A.; Blanco, M.J.; Del Barrio, M.G.; Portillo, F.; Nieto, M.A. The transcription factor snail controls epithelial-mesenchymal transitions by repressing E-cadherin expression. Nat. Cell Biol. 2000, 2, 76-83. [CrossRef]

178. Wang, J.J.; Zeng, Z.W.; Xiao, R.Z.; Xie, T.; Zhou, G.L.; Zhan, X.R.; Wang, S.L. Recent advances of chitosan nanoparticles as drug carriers. Int. J. Nanomed. 2011, 6, 765-774.

179. Yang, J.; Mani, S.A.; Donaher, J.L.; Ramaswamy, S.; Itzykson, R.A.; Come, C.; Savagner, P.; Gitelman, I.; Richardson, A.; Weinberg, R.A. Twist, a master regulator of morphogenesis, plays an essential role in tumor metastasis. Cell 2004, 117, 927-939. [CrossRef] 
180. Khan, M.A.; Chen, H.C.; Zhang, D.; Fu, J. Twist: A molecular target in cancer therapeutics. Tumor Biol. 2013, 34, 2497-2506. [CrossRef]

181. Meng, Q.; Meng, J.; Ran, W.; Wang, J.; Zhai, Y.; Zhang, P.; Li, Y. Light-activated core-shell nanoparticles for spatiotemporally specific treatment of metastatic triple-negative breast cancer. ACS Nano 2018, 12, 2789-2802. [CrossRef]

182. Glackin, C.A. Nanoparticle delivery of TWIST small interfering RNA and anticancer drugs: A therapeutic approach for combating cancer. In Enzymes; Elsevier Inc.: Amsterdam, The Netherlands, 2018; Volume 44, pp. 83-101. ISBN 9780128151112.

183. Zhao, B.; Xu, B.; Hu, W.; Song, C.; Wang, F.; Liu, Z.; Ye, M.; Zou, H.; Miao, Q.R. Comprehensive proteome quantification reveals $\mathrm{NgBR}$ as a new regulator for epithelial-mesenchymal transition of breast tumor cells. J. Proteom. 2015, 112, 38-52. [CrossRef] [PubMed]

184. Wang, B.; Zhao, B.; North, P.; Kong, A.; Huang, J.; Miao, Q.R. Expression of NgBR is highly associated with estrogen receptor alpha and survivin in breast cancer. PLoS ONE 2013, 8, e78083. [CrossRef] [PubMed]

185. Wu, D.; Zhao, B.; Qi, X.; Peng, F.; Fu, H.; Chi, X.; Miao, Q.R.; Shao, S. Nogo-B receptor promotes epithelial-mesenchymal transition in non-small cell lung cancer cells through the Ras/ERK/Snaill pathway. Cancer Lett. 2018, 418, 135-146. [CrossRef] [PubMed]

186. Danhier, F.; Le Breton, A.; Préat, V. RGD-based strategies to target alpha(v) beta(3) integrin in cancer therapy and diagnosis. Mol. Pharm. 2012, 9, 2961-2973. [CrossRef] [PubMed]

187. May, R.; Riehl, T.E.; Hunt, C.; Sureban, S.M.; Anant, S.; Houchen, C.W. Identification of a novel putative gastrointestinal stem cell and adenoma stem cell marker, doublecortin and CaM kinase-like-1, following radiation injury and in adenomatous polyposis coli/multiple intestinal neoplasia mice. Stem Cells 2008, 26, 630-637. [CrossRef]

188. May, R.; Sureban, S.M.; Hoang, N.; Riehl, T.E.; Lightfoot, S.A.; Ramanujam, R.; Wyche, J.H.; Anant, S.; Houchen, C.W. Doublecortin and CaM kinase-like-1 and leucine-rich-repeat-containing G-protein-coupled receptor mark quiescent and cycling intestinal stem cells, respectively. Stem Cells 2009, 27, 2571-2579. [CrossRef]

189. Sureban, S.M.; May, R.; Lightfoot, S.A.; Hoskins, A.B.; Lerner, M.; Brackett, D.J.; Postier, R.G.; Ramanujam, R.; Mohammed, A.; Rao, C.V.; et al. DCAMKL-1 regulates epithelial-mesenchymal transition in human pancreatic cells through a miR-200a-dependent mechanism. Cancer Res. 2011, 71, 2328-2338. [CrossRef]

190. Sureban, S.M.; May, R.; Ramalingam, S.; Subramaniam, D.; Natarajan, G.; Anant, S.; Houchen, C.W. Selective blockade of DCAMKL-1 results in tumor growth arrest by a let-7a microRNA-dependent mechanism. Gastroenterology 2009, 137, 649-659.e2. [CrossRef]

191. Prasad, C.P.; Mirza, S.; Sharma, G.; Prashad, R.; DattaGupta, S.; Rath, G.; Ralhan, R. Epigenetic alterations of $C D H 1$ and APC genes: Relationship with activation of $\mathrm{Wnt} / \beta$-catenin Pathway in invasive ductal carcinoma of breast. Life Sci. 2008, 83, 318-325. [CrossRef]

192. Saitoh, M.; Endo, K.; Furuya, S.; Minami, M.; Fukasawa, A.; Imamura, T.; Miyazawa, K. STAT3 integrates cooperative Ras and TGF- $\beta$ signals that induce Snail expression. Oncogene 2016, 35, 1049-1057. [CrossRef]

193. Silver, D.L.; Naora, H.; Liu, J.; Cheng, W.; Montell, D.J. Activated signal transducer and activator of transcription (STAT) 3: Localization in focal adhesions and function in ovarian cancer cell motility. Cancer Res. 2004, 64, 3550-3558. [CrossRef] [PubMed]

194. Nefedova, Y.; Gabrilovich, D. Targeting of Jak/STAT pathway in antigen presenting cells in cancer. Curr. Cancer Drug Targets 2007, 7,71-77. [CrossRef]

195. Meyer, A.S.; Miller, M.A.; Gertler, F.B.; Lauffenburger, D.A. The receptor AXL diversifies EGFR signaling and limits the response to EGFR-targeted inhibitors in triple-negative breast cancer cells. Sci. Signal. 2013, 6, ra66. [CrossRef] [PubMed]

196. Byers, L.A.; Diao, L.; Wang, J.; Saintigny, P.; Girard, L.; Peyton, M.; Shen, L.; Fan, Y.; Giri, U.; Tumula, P.K.; et al. An epithelial-mesenchymal transition gene signature predicts resistance to EGFR and PI3K inhibitors and identifies Axl as a therapeutic target for overcoming EGFR inhibitor resistance. Clin. Cancer Res. 2013, 19, 279-290. [CrossRef] [PubMed]

197. Peng, Y.; Croce, C.M. The role of microRNAs in human cancer. Signal Transduct. Target. Ther. 2016, 1, 15004. [CrossRef]

198. Chen, Y.; Gao, D.-Y.; Huang, L. In vivo delivery of miRNAs for cancer therapy: Challenges and strategies. Adv. Drug Deliv. Rev. 2015, 81, 128-141. [CrossRef] 
199. Croce, C.M. Causes and consequences of microRNA dysregulation in cancer. Nat. Rev. Genet. 2009, 10, 704-714. [CrossRef]

200. Li, Q.; Liang, X.; Wang, Y.; Meng, X.; Xu, Y.; Cai, S.; Wang, Z.; Liu, J.; Cai, G. MiR-139-5p inhibits the epithelial-mesenchymal transition and enhances the chemotherapeutic sensitivity of colorectal cancer cells by downregulating BCL2. Sci. Rep. 2016, 6, 27157. [CrossRef]

201. Liu, H.; Yin, Y.; Hu, Y.; Feng, Y.; Bian, Z.; Yao, S.; Li, M.; You, Q.; Huang, Z. -miR-139-5p sensitizes colorectal cancer cells to 5-fluorouracil by targeting NOTCH-1. Pathol. Res. Pract. 2016, 212, 643-649. [CrossRef]

202. Hadinoto, K.; Sundaresan, A.; Cheow, W.S. Lipid-polymer hybrid nanoparticles as a new generation therapeutic delivery platform: A review. Eur. J. Pharm. Biopharm. 2013, 85, 427-443. [CrossRef]

203. Dykxhoorn, D.M. MicroRNAs and metastasis: Little RNAs go a long way. Cancer Res. 2010, 70, 6401-6406. [CrossRef] [PubMed]

204. Korpal, M.; Kang, Y. The emerging role of miR-200 family of microRNAs in epithelial-mesenchymal transition and cancer metastasis. RNA Biol. 2008, 5, 115-119. [CrossRef] [PubMed]

205. Li, Y.; Vandenboom, T.G.; Kong, D.; Wang, Z.; Ali, S.; Philip, P.A.; Sarkar, F.H. Up-regulation of miR-200 and let-7 by natural agents leads to the reversal of epithelial-to-mesenchymal transition in gemcitabine-resistant pancreatic cancer cells. Cancer Res. 2009, 69, 6704-6712. [CrossRef] [PubMed]

206. Milán Rois, P.; Latorre, A.; Rodriguez Diaz, C.; del Moral, Á.; Somoza, Á. Reprogramming cells for synergistic combination therapy with nanotherapeutics against uveal melanoma. Biomimetics 2018, 3, 28. [CrossRef] [PubMed]

207. Pan, Y.; Zhang, J.; Fu, H.; Shen, L. miR-144 functions as a tumor suppressor in breast cancer through inhibiting ZEB1/2-mediated epithelial mesenchymal transition process. Oncol. Targets Ther. 2016, 9, 6247-6255. [CrossRef]

208. Imani, S.; Wei, C.; Cheng, J.; Khan, M.A.; Fu, S.; Yang, L.; Tania, M.; Zhang, X.; Xiao, X.; Zhang, X.; et al. MicroRNA-34a targets epithelial to mesenchymal transitioninducing transcription factors (EMT-TFs) and inhibits breast cancer cell migration and invasion. Oncotarget 2017, 8, 21362-21379. [CrossRef]

209. Choo, W.H.; Park, C.H.; Jung, S.E.; Moon, B.; Ahn, H.; Ryu, J.S.; Kim, K.S.; Lee, Y.H.; Yu, I.J.; Oh, S.M. Long-term exposures to low doses of silver nanoparticles enhanced in vitro malignant cell transformation in non-tumorigenic BEAS-2B cells. Toxicol. In Vitro 2016, 37, 41-49. [CrossRef]

210. Gliga, A.R.; Di Bucchianico, S.; Lindvall, J.; Fadeel, B.; Karlsson, H.L. RNA-sequencing reveals long-term effects of silver nanoparticles on human lung cells. Sci. Rep. 2018, 8, 6668. [CrossRef]

211. Guo, C.; You, D.Y.; Li, H.; Tuo, X.Y.; Liu, Z.J. Spherical silica nanoparticles promote malignant transformation of BEAS-2B cells by stromal cell-derived factor- $1 \alpha$ (SDF-1 $\alpha$ ). J. Int. Med. Res. 2019, 47, 1264-1278. [CrossRef]

212. Ma, J.; Bishoff, B.; Mercer, R.R.; Barger, M.; Schwegler-Berry, D.; Castranova, V. Role of epithelial-mesenchymal transition (EMT) and fibroblast function in cerium oxide nanoparticles-induced lung fibrosis. Toxicol. Appl. Pharm. 2017, 323, 16-25. [CrossRef]

213. Wang, P.; Voronkova, M.; Luanpitpong, S.; He, X.; Riedel, H.; Dinu, C.Z.; Wang, L.; Rojanasakul, Y. Induction of slug by chronic exposure to single-walled carbon nanotubes promotes tumor formation and metastasis. Chem. Res. Toxicol. 2017, 30, 1396-1405. [CrossRef] [PubMed]

214. Polimeni, M.; Gulino, G.R.; Gazzano, E.; Kopecka, J.; Marucco, A.; Fenoglio, I.; Cesano, F.; Campagnolo, L.; Magrini, A.; Pietroiusti, A.; et al. Multi-walled carbon nanotubes directly induce epithelial-mesenchymal transition in human bronchial epithelial cells via the TGF- $\beta$-mediated Akt/GSK-3 $\beta /$ SNAIL-1 signalling pathway. Part. Fibre Toxicol. 2015, 13, 27. [CrossRef] [PubMed]

215. Wang, P.; Wang, Y.; Nie, X.; Braïni, C.; Bai, R.; Chen, C. Multiwall carbon nanotubes directly promote fibroblast-myofibroblast and epithelial-mesenchymal transitions through the activation of the TGF- $\beta / \mathrm{Smad}$ signaling pathway. Small 2015, 11, 446-455. [CrossRef] [PubMed]

216. Lohcharoenkal, W.; Wang, L.; Stueckle, T.A.; Park, J.; Tse, W.; Dinu, C.Z.; Rojanasakul, Y. Role of H-Ras/ERK signaling in carbon nanotube-induced neoplastic-like transformation of human mesothelial cells. Front. Physiol. 2014, 5, 222. [CrossRef] [PubMed]

217. Chen, T.; Nie, H.; Gao, X.; Yang, J.; Pu, J.; Chen, Z.; Cui, X.; Wang, Y.; Wang, H.; Jia, G. Epithelial-mesenchymal transition involved in pulmonary fibrosis induced by multi-walled carbon nanotubes via TGF-beta/Smad signaling pathway. Toxicol. Lett. 2014, 226, 150-162. [CrossRef] 
218. Hong, F.; Hong, J.; Wang, L.; Zhou, Y.; Liu, D.; Xu, B.; Yu, X.; Sheng, L. Chronic exposure to nanoparticulate $\mathrm{TIO}_{2}$ causes renal fibrosis involving activation of the Wnt pathway in mouse kidney. J. Agric. Food Chem. 2015, 63, 1639-1647. [CrossRef]

219. Li, G.; Huang, Y.; Liu, Y.; Guo, L.; Zhou, Y.; Yang, K.; Chen, Y.; Zhao, G.; Lei, Y. In vitro toxicity of naturally occurring silica nanoparticles in C1 coal in bronchial epithelial cells. Zhongguo Fei Ai Za Zhi 2012, 15, 561-568.

220. Ma, J.Y.; Mercer, R.R.; Barger, M.; Schwegler-Berry, D.; Scabilloni, J.; Ma, J.K.; Castranova, V. Induction of pulmonary fibrosis by cerium oxide nanoparticles. Toxicol. Appl. Pharm. 2012, 262, 255-264. [CrossRef]

221. Park, E.J.; Cho, W.S.; Jeong, J.; Yi, J.H.; Choi, K.; Kim, Y.; Park, K. Induction of inflammatory responses in mice treated with cerium oxide nanoparticles by intratracheal instillation. J. Heal. Sci. 2010, 56, 387-396. [CrossRef]

222. Ema, M.; Gamo, M.; Honda, K. A review of toxicity studies of single-walled carbon nanotubes in laboratory animals. Regul. Toxicol. Pharm. 2016, 74, 42-63. [CrossRef]

223. Wang, L.; Luanpitpong, S.; Castranova, V.; Tse, W.; Lu, Y.; Pongrakhananon, V.; Rojanasakul, Y. Carbon nanotubes induce malignant transformation and tumorigenesis of human lung epithelial cells. Nano Lett. 2011, 11, 2796-2803. [CrossRef] [PubMed]

224. Nagai, H.; Okazaki, Y.; Chew, S.H.; Misawa, N.; Yamashita, Y.; Akatsuka, S.; Ishihara, T.; Yamashita, K.; Yoshikawa, Y.; Yasui, H.; et al. Diameter and rigidity of multiwalled carbon nanotubes are critical factors in mesothelial injury and carcinogenesis. Proc. Natl. Acad. Sci. USA 2011, 108, E1330-E1338. [CrossRef]

225. Gui, S.; Li, B.; Zhao, X.; Sheng, L.; Hong, J.; Yu, X.; Sang, X.; Sun, Q.; Ze, Y.; Wang, L.; et al. Renal injury and $\mathrm{Nrf} 2$ modulation in mouse kidney following chronic exposure to $\mathrm{TiO}_{2}$ nanoparticles. J. Agric. Food Chem. 2013, 61, 8959-8968. [CrossRef] [PubMed]

226. Lee, S.B.; Kalluri, R. Mechanistic connection between inflammation and fibrosis. Kidney Int. 2010, 78, S22-S26. [CrossRef] [PubMed]

227. Wang, X.; Sun, B.; Liu, S.; Xia, T. Structure activity relationships of engineered nanomaterials in inducing NLRP3 inflammasome activation and chronic lung fibrosis. NanoImpact 2017, 6, 99-108. [CrossRef]

228. Yan, S.; Li, X.; Dai, J.; Wang, Y.; Wang, B.; Lu, Y.; Shi, J.; Huang, P.; Gong, J.; Yao, Y. Electrospinning of PVA/sericin nanofiber and the effect on epithelial-mesenchymal transition of A549 cells. Mater. Sci. Eng. C 2017, 79, 436-444. [CrossRef]

229. Li, X.; Yan, S.; Dai, J.; Lu, Y.; Wang, Y.; Sun, M.; Gong, J.; Yao, Y. Human lung epithelial cells A549 epithelial-mesenchymal transition induced by PVA/Collagen nanofiber. Colloids Surf. B Biointerfaces 2018, 162, 390-397. [CrossRef] 